\title{
1 Isotopic studies of the Upper and Middle Rio Grande. Part 1 - Importance of sulfide weathering in the riverine sulfate budget.
}

\author{
Anna Szynkiewicz ${ }^{1,2}$, , David M. Borrok ${ }^{3,2}$, Grzegorz Skrzypek ${ }^{4}$, Michael Rearick ${ }^{5}$ \\ ${ }^{1}$ Earth and Planetary Sciences, University of Tennessee, 1412 Circle Drive, Knoxville, TN, USA \\ ${ }^{2}$ Geological Sciences, University of Texas at El Paso, 500 W. University Ave., El Paso, TX, USA \\ ${ }^{3}$ School of Geosciences, University of Louisiana at Lafayette, 611 McKinley St., P.O. Box 44650, \\ Lafayette, LA 70504, USA \\ ${ }^{4}$ West Australian Biogeochemistry Centre, School of Plant Biology, The University of Western Australia, \\ 35 Stirling Highway, Crawley WA 6009, Australia \\ ${ }^{5}$ EES-14 Earth System Observations, Los Alamos National Laboratory, Los Alamos, NM 87545, USA \\ *corresponding author: aszynkie@utk.edu, phone: 865-974-6006, fax: 865-974-2368
}

\begin{abstract}
In order to characterize the sulfide-derived $\mathrm{SO}_{4}$ fluxes in the Rio Grande, we collected seasonally (from 2009 to 2011) riverine, agricultural drain and groundwater samples and analyzed them for their major element chemistries and the $\delta^{34} \mathrm{~S}$ and $\delta^{18} \mathrm{O}$ of dissolved $\mathrm{SO}_{4}$. The observed variation of $\delta^{34} \mathrm{~S}(-4$ to $+8 \%$ ) and $\delta{ }^{18} \mathrm{O}(-2$ to $+7 \%$ ) in the Rio Grande mainly resulted from mixing between sulfide- and sulfate-derived $\mathrm{SO}_{4}$ of volcanic and sedimentary origin. Our $\mathrm{S}$ isotope mass balance suggests that the average sulfide-derived $\mathrm{SO}_{4}$ flux usually accounted for $83-94 \%( \pm 10-20 \%)$ of the sulfate source in the upstream Rio Grande and decreased downstream to 45-51\% because of increasing contributions of sulfate-derived $\mathrm{SO}_{4}$. The sulfide-derived $\mathrm{SO}_{4}$ was related to snow melt in the high elevation watersheds and recycling of surficial sulfate-rich salts by episodic water activity in dry areas at lower elevations. Additionally, elevated bedrock sulfide contents in volcanic and some sedimentary terrains of the studied area have been recognized as important factors contributing to sulfide-derived $\mathrm{SO}_{4}$ in the Rio Grande.
\end{abstract}

\section{Introduction}

Sulfide weathering is a biogeochemical process that releases sulfuric acid $\left(\mathrm{H}_{2} \mathrm{SO}_{4}\right)$ into aquatic environments, accelerating the dissolution of rocks (e.g.; Vear and Curtis, 1981; Fennemore et al., 1998; Andersen et al., 2001; Balci et al., 2013). Given that sulfide oxidation is driven by $\mathrm{O}_{2}$ in surface environments (Eq. 1), this process is believed to be partly important in controlling atmospheric $\mathrm{O}_{2}$ levels over geological time (e.g., Bottrell and Newton, 2006). Indirectly, sulfide weathering can also affect the atmospheric $\mathrm{CO}_{2}$ budget (Hercod et al., 1998; Calmels et al. 2007; Li et al., 2008). For example, sulfide oxidation in carbonate-rich catchments (Eq. 2) and the ultimate precipitation of this carbonate in ocean systems (Eq. 3) results in a net gain of $\mathrm{CO}_{2}$ to the atmosphere (Walker et al., 1981; Berner et al., 1983): 
$\mathrm{FeS}_{2}+3.5 \mathrm{O}_{2}+\mathrm{H}_{2} \mathrm{O} \rightarrow \mathrm{Fe}^{2+}+2 \mathrm{SO}_{4}{ }^{2-}+2 \mathrm{H}^{+}$

$2 \mathrm{CaCO}_{3}+\mathrm{H}_{2} \mathrm{SO}_{4} \rightarrow 2 \mathrm{Ca}^{2+}+2 \mathrm{HCO}_{3}{ }^{-}+\mathrm{SO}_{4}{ }^{2-}$

$\mathrm{Ca}^{2+}+2 \mathrm{HCO}_{3}^{-} \rightarrow \mathrm{CaCO}_{3}+\mathrm{CO}_{2} \uparrow+\mathrm{H}_{2} \mathrm{O}$

Current geochemical models assume that $\mathrm{H}_{2} \mathrm{SO}_{4}$ dissolution via sulfide oxidation is negligible on global scales because of trace/minor sulfide contents in the lithosphere. (e.g., Berner and Berner, 1996; François and Walker, 1992). The assumption is often that much of the sulfate $\left(\mathrm{SO}_{4}\right)$ flux comes from nonsulfide sources (e.g., dissolution of marine-origin gypsum/anhydrite). However, recent geochemical studies indicate that previous estimates on sulfide-derived $\mathrm{SO}_{4}$ fluxes used in elemental cycle models (e.g., Berner and Berner, 1996; François and Walker, 1992) are significantly underestimated (Calmels et al., 2007; Das et al., 2012). Generally, the reported sulfide-derived $\mathrm{SO}_{4}$ fluxes appear to span a large range of $\sim 15$ to almost $100 \%$ in aquatic systems (Tab. 1) when compared to other $\mathrm{SO}_{4}$ fluxes from dissolution of evaporites and atmospheric wet/dry deposition. Therefore, sulfide weathering may have important implications on how we understand the Earth's climate (Eqs. 1, 3) and the evolution of biogeochemical sulfur (S) cycle over geological time scales. Despite this importance, there are still only a small number of studies that attempt to quantify sulfide-derived $\mathrm{SO}_{4}$ fluxes in global riverine systems (Tab. 1). It is also uncertain to what extent environmental factors (e.g., physical erosion, bedrock sulfide content) and climate influence these fluxes in aquatic environments.

Most of quantitative models calculating sulfide-derived $\mathrm{SO}_{4}$ fluxes (Tab. 1) are formulated using $\mathrm{S}$ isotope mass balance constraints. This is mainly because large $\mathrm{S}$ isotope variation exists in Earth's rocks ( $\sim 80-100 \%$ ) but small $\mathrm{S}$ isotope fractionations ( 1-2\%) are involved during the oxidation/dissolution of S-bearing minerals (e.g., Nakai and Jensen, 1964; Toran and Harris, 1981; Krouse and Grinenko; 1991; Raab and Spiro, 1991; Clark and Fritz, 1997). Consequently, the $\delta^{34} \mathrm{~S}_{\text {of }} \mathrm{SO}_{4}$ can precisely pinpoint major bedrock sources of $\mathrm{S}$ (sulfides, evaporites) participating in water-rock interaction. Furthermore, the importance of atmospheric $\mathrm{O}_{2}$ in sulfide oxidation (Eq. 1) can be roughly distinguished by measuring the $\delta^{18} \mathrm{O}$ of $\mathrm{SO}_{4}$ since atmospheric $\mathrm{O}_{2}$ is characterized by significantly higher $\delta^{18} \mathrm{O}(+23.5 \%$ compared to water oxygen in continental rivers (<-5 \%) (e.g., Krouse and Grinenko; 1991; Clark and Fritz, 1997). However, the atmospheric $\mathrm{O}_{2}$ signature in $\mathrm{SO}_{4}$ can be to some degree altered by $\mathrm{O}$ isotope exchange between water and intermediate $\mathrm{S}$ compounds during oxidation of sulfides to $\mathrm{SO}_{4}$ (e.g., Bottrell and Tranter, 2002; Tichomirowa and Junghans, 2009).

In order to better quantify and evaluate factors controlling the flux of sulfide-derived $\mathrm{SO}_{4}$ on a regional scale, we investigated seasonal $\mathrm{SO}_{4}$ fluxes and changes of its $\mathrm{S}$ and $\mathrm{O}$ isotope composition in the 
Rio Grande over a distance of $1500 \mathrm{~km}$, from the headwaters of the river in South Colorado to West Texas. The Rio Grande watershed is an ideal field site to study sulfide-derived $\mathrm{SO}_{4}$ fluxes because the $\delta^{34} \mathrm{~S}$ value in bedrock sulfides $(-22.3$ to $+2.7 \%)$ and sulfate minerals $(+6.6$ to $+18.0 \%$ ) have distinct signatures allowing for better estimates of sulfide-derived $\mathrm{SO}_{4}$ fluxes in the aquatic system (Kirkland et al., 1995; Nordstrom et al., 2007; Campbell and Lueth, 2008; Szynkiewicz et al., 2011, 2014). Additionally, relatively high differences in altitude ( $\sim 1400$ to $3500 \mathrm{~m}$ above see level) and the prevailing semi-arid climate in the downstream Rio Grande study area allow for evaluating the role of environmental conditions (e.g., physical weathering, wet versus dry climate) on sulfide-derived $\mathrm{SO}_{4}$ fluxes.

\section{Environmental Setting}

The Rio Grande is the fourth longest river system in the United States. From its headwaters in Colorado to west Texas it flows from north to south along the Rio Grande Valley. The Rio Grande flows through a series of alluvial-fill basins formed by half grabens that developed in the Rio Grande rift $\sim 30$ Ma ago during an episode of widespread extension of the western United States (Keller and Baldridge, 1999). These basins are filled with alluvial, fluvial, playa, and lacustrine sediments (range in depth from less than $30 \mathrm{~m}$ to $4,000 \mathrm{~m}$ ) derived from erosion of adjacent Precambrian crystalline and Paleozoic/Mesozoic sedimentary bedrock highlands (Keller and Cather, 1994). Recharge to the alluvialfill basins mainly occurs from mountain catchments runoff, inflow from adjacent aquifers, and infiltration of water from both the Rio Grande and its adjacent irrigation network (Ellis et al., 1993; Witcher et al., 2004, Sanford et al., 2004; Anning et al., 2007; Eastoe et al., 2008). Average annual precipitation delivered to the Rio Grande is less than $254 \mathrm{~mm}$ (Ellis et al., 1993). Major recharge to the Rio Grande is during the spring from snowmelt in the headwater region of the San Juan Mountains in southwestern Colorado and in the high mountain areas of northern New Mexico.

In the studied area, the Rio Grande is regulated by several dams and reservoirs that are used to store water for municipal and agricultural purposes. From north to south, these include the Rio Grande Reservoir in the headwater region, Cochiti Lake near Albuquerque, New Mexico, and the Elephant Butte and the Caballo reservoirs in southern New Mexico. Additionally, the Heron, El Vado and Abiquiu reservoirs are located along the Rio Chama (Fig. 1), a main tributary to the Rio Grande in northern New Mexico. Some of the surface water in the Rio Chama is diverted from the opposite side of the continental divide in southwestern Colorado via a $\sim 40 \mathrm{~km}$ long series of pipelines and tunnels that are part of the San Juan-Chama Drinking Water Project. The project is part of a major effort to make Rio Grande surface water the primary drinking water source for the Albuquerque metro area and to protect the aquifer resources in central New Mexico. 


\section{Methods}

\subsection{Field sampling}

In August and November/December of 2009 and in April/May of 2010 surface water samples were collected from the Rio Grande in locations 1 through 21 (Fig. 1), from the river's headwaters (southern Colorado) to the Indio Mountains Research Station ( $\sim 300 \mathrm{~km}$ southeast of El Paso, Texas). In addition to surface water samples in the Rio Grande, we sampled the major Rio Grande tributaries in northern New Mexico (e.g., Red River [Loc. 28-32], Hondo River [Loc. 4], Rio Chama [Loc. 33-38], and Rio Puerco [Loc. 39-40]) and groundwater from major alluvial basins (e.g., the Española [Loc. 60-68], Albuquerque [Loc. 69-72], Socorro [Loc. 73-76], and Mesilla [Loc. 78-84] in New Mexico and the Hueco-Bolson [Loc. 85-88] in West Texas (Fig. 1). The surface water samples along the Rio Chama were collected in November 2011 and April 2012. Additional groundwater samples were collected from wells with temperatures higher $\left(>18-30^{\circ} \mathrm{C}\right)$ than typical background values in the Bosque del Apache Wildife Refuge (Loc. 73-76), central New Mexico and near Fabens (Loc. 86-88), Texas. Furthermore, two water samples were collected from an artesian well with geothermal water (at the surface $41^{\circ} \mathrm{C}$ ) in Truth or Consequences (Loc. 77), New Mexico and from a municipal well with low-temperature aquifer water (at the surface $27^{\circ} \mathrm{C}$ ) used by the El Paso, Texas, Desalination Plant (Loc. 85). Between 2010 and 2011, waste water effluents were collected from major cities in the Rio Grande study area, including Santa Fe (Loc.55), Albuquerque (Loc. 56), and Las Cruces (Loc. 57), New Mexico, and from El Paso, Texas (Loc. 58-59).

In all locations, the sampled water was filtered in the field with a $0.45 \mu \mathrm{m}$ nylon syringe filter into two $125 \mathrm{~mL}$ plastic bottles. One portion of water was acidified with 16 drops of high-purity concentrated $\mathrm{HNO}_{3}$ for cation analysis. The second portion was left untreated for anion analysis. Unfiltered surface water samples were collected in 0.25-1.0 L plastic bottles that were rinsed three times with the river water prior to sampling. These were processed and analyzed for their $\mathrm{S}$ and $\mathrm{O}$ isotope compositions of dissolved sulfate $\left(\mathrm{SO}_{4}\right)$. Temperature, $\mathrm{pH}$, and conductivity were measured in situ for surface water and groundwater samples using an Orion portable meter (Thermo Scientific 3 Star Multimeter). Except for field campaigns in Aug/Nov 2009, alkalinity was measured in the field using a LaMotte titration kit (LaMotte Company, Maryland, USA) with analytical error of $\pm 4 \mathrm{mg} / \mathrm{L}$.

\subsection{Chemical analysis}

The concentrations of cations in all water samples were measured using a Perkin Elmer 5300 DV Inductively Coupled Plasma-Optical Emission Spectrometer (ICP-OES) at the University of Texas at El Paso. Samples were analyzed using multi-element atomic adsorption standards (diluted from 10.00 mg/L 
stock solutions) and U.S. Geological Survey standard reference water samples were used as an external check of precision and accuracy. The concentrations of anions in all water samples were measured using EPA method 300 on a Dionex DX-600 equipped with conductivity detection at Los Alamos National Laboratory. An AG14 guard column and AS14 separator column were used in conjunction with a Dionex ASRS $3002 \mathrm{~mm}$ suppressor to separate the anion species and reduce the background conductivity. The mobile phase composition was $3.5 \mathrm{mM} \mathrm{Na}_{2} \mathrm{CO}_{3}$ and $1.0 \mathrm{mM} \mathrm{NaHCO}$. Calibration standards were prepared from a stock solution of anions purchased from SPEX Certiprep. Samples were diluted and rerun in cases where elemental concentrations were outside the initial calibration range. Because of required dilution, particularly for the samples of river/drain/well water showing higher salinity $(1-5 \mathrm{mS} / \mathrm{cm})$, the analytical uncertainty was considerably higher (10 to $20 \%)$ as compared to the water samples with low ion concentrations $(<0.5 \mathrm{mS} / \mathrm{cm} ;<5 \%)$.

\section{3. $S$ and $O$ isotope analysis}

All collected surface water and groundwater samples were analyzed for their $\mathrm{S}$ and $\mathrm{O}$ isotope compositions of dissolved $\mathrm{SO}_{4}\left(\delta^{34} \mathrm{~S}\right.$ and $\delta^{18} \mathrm{O}$, respectively). After arrival in the laboratory, raw water samples were filtered and dissolved $\mathrm{SO}_{4}$ was precipitated as $\mathrm{BaSO}_{4}$ by reaction with $10-20 \mathrm{~mL}$ of $10 \%$ $\mathrm{BaCl}_{2}$. Prior to drying, the $\mathrm{BaSO}_{4}$ precipitate was rinsed several times with DI-water. The $\delta^{34} \mathrm{~S}_{\text {of }} \mathrm{BaSO}_{4}$ was determined using an EA1110 elemental analyzer coupled to a Finnigan Mat 252 isotope ratio mass spectrometer via a ConFlo II split interface in the Stable Isotope Research Facility at Indiana University. $\mathrm{S}$ isotopic data are reported with respect to VCDT (Vienna Cañon Diablo Troilite). Analytical reproducibility was better than $0.3 \%$ based on sample duplicates. Given that the water samples were not filtered in situ in the field, we subsequently repeated precipitation of $\mathrm{BaSO}_{4}$ on several samples stored in the laboratory for 3-4 months. Consequently, the measured $\delta^{34} \mathrm{~S}$ of $\mathrm{BaSO}_{4}$ was within the analytical error of $+/-0.3 \%$ compared to the $\mathrm{BaSO}_{4}$ of water samples processed a few hours after sampling.

The $\delta^{18} \mathrm{O}$ of $\mathrm{BaSO}_{4}$ was analyzed in a continuous flow system using a high temperature conversion elemental analyzer (TC/EA) coupled with Delta XL Mass Spectrometer (Thermo-Fisher Scientific, Bremen Germany) at the University of Western Australia. $\mathrm{BaSO}_{4}$ was thermally decomposed in a highlyreductive environment and $\delta^{18} \mathrm{O}$ was analyzed in the $\mathrm{CO}$ gas yielded, which was carried in helium stream. The raw $\delta$-values were normalized using a multipoint normalization technique (Skrzypek and Sadler 2011; Skrzypek, 2013) based on international standards (IAEA601, IAEA602, SO-5, SO-6 and NBS127) provided by International Atomic Energy Agency from Vienna (IAEA). Analytical reproducibility was better than $0.3 \%$ based on duplicates. 


\subsection{Mass flux calculations}

We were able to reconstruct the volumetric flow rates for a number of the sampling sites using a combination of online gauging station data collected from the U.S. Geological Survey, the U.S. International Boundary and Water Commission, and the El Paso County Water Improvement District No.1. In most cases, we were able to pinpoint the flow rates for the exact days and sampling locations, but for a few samples it was necessary to use information collected from nearby locations (not more than a few kilometers from the sample site). Using these volumetric flow rates we were able to calculate elemental mass loads for most river water samples by multiplying the stream water concentrations (in $\mathrm{mg} / \mathrm{L}$ ) by the flow rates (in $\mathrm{L} / \mathrm{s}$ ) and then converting the units of $\mathrm{mg} / \mathrm{s}$ to $\mathrm{kg} / \mathrm{day}$ and finally metric tons/day.

\section{Results}

\subsection{Water Chemistry}

In all investigated seasons, we found a steady increase in electric conductivity (EC) with increasing distance from the headwater region (Fig. 2A). EC ranged from $\sim 0.06-0.20 \mathrm{mS} / \mathrm{cm}$ in southern Colorado to $\sim 2.80-4.50 \mathrm{mS} / \mathrm{cm}$ in west Texas (Suppl. Tab. 1). In the semi-arid portion of the Rio Grande, the EC was always lower by $\sim 1-2 \mathrm{mS} / \mathrm{cm}$ during the irrigation season (Aug 2009, Apr/May 2010) compared to the non-irrigation season (Nov 2009). Consequently, a similar pattern was observed for concentrations of major ions (Suppl. Tab. 1). Increases in concentrations from the headwaters to west Texas were observed for all major ions, including $\mathrm{SO}_{4}(\sim 3-20$ to $500-750 \mathrm{mg} / \mathrm{L}), \mathrm{Cl}(\sim 1-6$ to $300-900 \mathrm{mg} / \mathrm{L}), \mathrm{Na}(\sim 5-10$ to $100-$ $600 \mathrm{mg} / \mathrm{L}), \mathrm{HCO}_{3}(\sim 40-80$ to $200-250 \mathrm{mg} / \mathrm{L}), \mathrm{Ca}(\sim 10-25$ to $60-200 \mathrm{mg} / \mathrm{L}), \mathrm{K}(\sim 1-5$ to $10-40 \mathrm{mg} / \mathrm{L})$, and Mg ( 1-7 to 30-50 mg/L) (Fig. 2BC). Furthermore, the concentrations were always lower in the irrigation season, as the extra water released from upstream dams had a dilution effect (Suppl. Tab. 1). The sampled agricultural drains showed slightly higher average EC and ion concentrations compared to the Rio Grande (Fig. 2).

The concentrations of $\mathrm{SO}_{4}, \mathrm{Cl}$, and $\mathrm{Na}$ in the waste water effluents of major cities along the Rio Grande increased southward from Santa Fe in northern New Mexico to El Paso, Texas ( 600 km distance) from 45 to $530 \mathrm{mg} / \mathrm{L}, 70$ to $240 \mathrm{mg} / \mathrm{L}$, and 90 to $370 \mathrm{mg} / \mathrm{L}$, respectively (Suppl. Tab. 1). The concentrations of $\mathrm{HCO}_{3}, \mathrm{Ca}, \mathrm{Mg}$, and $\mathrm{K}$ did not vary substantially among the waste water samples. The average concentrations of these elements were $\sim 180 \mathrm{mg} / \mathrm{L}, \sim 60 \mathrm{mg} / \mathrm{L}, \sim 15 \mathrm{mg} / \mathrm{L}$, and $\sim 20 \mathrm{mg} / \mathrm{L}$, respectively (Suppl. Tab. 1).

Generally, the highest fluxes were observed for $\mathrm{HCO}_{3}$ and $\mathrm{SO}_{4}(\sim 10$ to 1000 metric tons/day) compared to smaller fluxes of $\mathrm{Cl}, \mathrm{Na}$, and $\mathrm{Ca}(\sim 1$ to 300 metric tons/day) (Fig. 3; Suppl. Tab. 1). In 
November 2009 and April 2010, the fluxes of $\mathrm{HCO}_{3}, \mathrm{SO}_{4}, \mathrm{Na}, \mathrm{Cl}$ and $\mathrm{Ca}$ increased from the headwaters in Southern Colorado to San Antonio (Loc. 10) in central New Mexico (Fig. 3). Below San Antonio, the ion fluxes considerably decreased in both investigated seasons, except for the Indio Research Station in west Texas (Loc. 21) in November 2009 (Fig. 3A).

\section{2. $S$ and $O$ isotope compositions}

In Nov/Dec 2009 and Apr/May 2010, the $\delta^{34} \mathrm{~S}$ and $\delta^{18} \mathrm{O}$ of dissolved $\mathrm{SO}_{4}$ in the Rio Grande changed considerably over the $\sim 1500 \mathrm{~km}$ distance from the headwaters region to the Indio Research Station in west Texas, from -3.7 to $+8.0 \%$ and from -2.2 to $+7.1 \%$ for $\mathrm{S}$ and $\mathrm{O}$ isotopes, respectively (Fig. $4 \mathrm{AB}$; Suppl. Tab. 1). Except for Alamosa, Colorado (Loc. 2) and Truth or Consequences, New Mexico (Loc. 13) that exhibited local increases in $\delta^{34} \mathrm{~S}$ (up to $\sim 8 \%$ and $5 \%$, respectively), we generally observed lower values for $\delta^{34} \mathrm{~S}\left(+0.4\right.$ to $-2.4 \%$ ) in northern New Mexico (Loc. 1-8) and increasingly higher $\delta^{34} \mathrm{~S}$ values $(-0.6$ to $+3.6 \%$ ) downstream in the semi-arid portions of the Rio Grande in central/southern New Mexico and West Texas (Loc. 9-21). With few exceptions the $\delta^{18} \mathrm{O}$ steadily increased over the studied $\sim 1500 \mathrm{~km}$ distance, from -0.1 to $+6.6 \%$. Alamosa, Colorado (Loc. 2) was an exception in that it had a higher $\delta^{18} \mathrm{O}$ than the surrounding samples (Fig. 4B). Most of the collected drain water samples showed very similar increases of $\delta^{34} \mathrm{~S}$ and $\delta^{18} \mathrm{O}$ as were observed for the Rio Grande relative to the distance from headwaters, ranging on average from +0.9 to $+3.2 \%$ and from +4.7 to $+7.3 \%$, respectively (Fig. $4 \mathrm{AB}$; Suppl. Tab. 1).

The $\delta^{34} \mathrm{~S}$ and $\delta^{18} \mathrm{O}$ of the groundwater samples varied substantially over the study area (Fig. 5). The lowest values ( -17.1 to $+3.6 \%$ and -0.9 to $+5.6 \%$ for $\mathrm{S}$ and $\mathrm{O}$ isotopes, respectively) were noted in the Rio Grande recharge areas of northern New Mexico (Locations 60 through 78), which are dominated by crystalline/volcanic bedrock (Figure 5; Suppl. Tab. 1). Conversely, the highest $\delta^{34} \mathrm{~S}$ values of groundwater $(+5.4$ to $+10.5 \%$ and +5.1 to $+11.2 \%$ for $\mathrm{S}$ and $\mathrm{O}$ isotopes, respectively) were observed in central/southern New Mexico and west Texas, which is dominated by Paleozoic sedimentary bedrock (Locations 74 through 85). Additionally, we noted a distinctively lower $\delta^{18} \mathrm{O}$ of $+3.5 \%$ for the saline geothermal groundwater $(5 \mathrm{mS} / \mathrm{cm})$ in Truth or Consequences (Loc. 77) compared to a higher $\delta^{18} \mathrm{O}$ of $+11.2 \%$ in the low-temperature saline groundwater $(6 \mathrm{mS} / \mathrm{cm})$ in east El Paso, Texas (desalination plant; Loc.85; Fig. 5, Suppl. Tab. 1). Despite these differences in $\delta^{18} \mathrm{O}$, these two water samples had similar $\delta^{34} \mathrm{~S}$ values of $+9.1 \%$ and $+10.5 \%$, respectively, and similar sedimentary bedrock mineralogy.

The $\delta^{34} \mathrm{~S}$ of the waste effluents in major cities was always higher by 2-3\%o than that of the corresponding Rio Grande surface water samples. But like the Rio Grande water, the $\delta^{34} \mathrm{~S}$ of the waste effluents increased downstream (from +1.5 to $+7.1 \%$; Fig. $4 \mathrm{~A}$ ). In contrast, the $\delta^{18} \mathrm{O}$ of the waste water 
effluent samples varied over a small range $(+1.7$ to $+3.0 \%)$ and did not increase downstream like the Rio Grande water (Fig. 4B).

\section{Discussion}

\subsection{Water chemistry and ion fluxes}

Primary recharge to the Rio Grande is controlled by spring snowmelt in the San Juan, Sangre de Cristo, and Jemez mountain ranges (Fig. 1). The dominant bedrock type of the recharge areas (Loc. 1-7) is Precambrian igneous and metamorphic rocks and Tertiary acidic and basaltic volcanic intrusions that are hydrothermally altered and mineralized to varied degrees (e.g., Nordstrom et al. 2007; Campbell and Lueth, 2008). In contrast, the Paleozoic and Mesozoic sedimentary formations of marine and continental origin (e.g., carbonates, evaporites, sandstone, mudstones, shale, coal) are more common to the south (Loc. 8-21). Additionally, in central/south New Mexico and west Texas the Rio Grande flows through a semi-arid portion of the Chihuahuan Desert with significantly lower precipitation rates compared to the high mountain areas in in southern Colorado and northern New Mexico. In arid zones, high surface temperatures are important in increasing evaporation rates, which can increase ion concentrations in solution (Yuan and Miyamoto, 2005, 2008; Yuan et al., 2007) as well as the accumulation of surficial salts between precipitation events (e.g., Abu-Jaber, 2001; Mees, 2003; Jia et al., 2011; Szynkiewicz et al., 2014). The evaporative increases in ion concentrations are estimated to be as high as $33-35 \%$ in the dry areas of central and southern New Mexico (Phillips et al., 2003; Yuan and Miyamoto, 2008).

Accordingly, we observed steady increases in EC and concentrations of all major ions with increasing distance from headwaters (Fig. 2). Our observations fit a model of evaporative enrichment due to increasing aridity in downstream locations. While the concentrations of dissolved $\mathrm{SO}_{4}, \mathrm{HCO}_{3}$ and $\mathrm{Ca}$ remained proportionally high along the studied distance (Suppl. Tab. 1), the concentrations of $\mathrm{Na}$ and $\mathrm{Cl}$ were relatively small $(<5-15 \mathrm{mg} / \mathrm{L})$ in upstream locations dominated by the Precambrian crystalline and Tertiary volcanic bedrock. Conversely, the concentrations of $\mathrm{Na}$ and $\mathrm{Cl}$ were significantly higher (50-350 $\mathrm{mg} / \mathrm{L}$ ) in downstream locations dominated by the Paleozoic and Mesozoic sedimentary-rich bedrock. This suggests that the increasing abundance of the sedimentary rocks in central/south New Mexico and west Texas is most likely another important factor increasing concentrations of major ions in the Rio Grande.

Because in our study the measured ion fluxes are largely dependent on surface water flow (see chapter 3.4 for more details), they were more controlled by man-made regulation of the Rio Grande flow. For example, in upstream Rio Grande (Loc. 1-10) the significant increases of ion fluxes in April 2010 were most likely controlled by elevated water releases from upstream reservoirs for irrigation (Fig. 3B). However, we speculate that there is also some natural groundwater recharge to the upstream Rio Grande 
from surrounding highlands because of more precipitation (snow/rain) at these higher elevations. The steady increase of ion fluxes in Locations 1 through 7 during base-flow conditions in November 2009 (i.e., when water releases from upstream reservoirs for irrigation were less important) supports this suggestion (Fig. 3A).

Conversely, in the semi-arid reach (Loc. 11-20) the ion fluxes showed decreasing trends with increasing distance from the Elephant Butte reservoir in southern New Mexico (Fig. 3). This can be explained by less natural recharge in dry areas, mainly limited to a summer monsoon, and the diversion of the Rio Grande water for irrigation to support agricultural districts in the Las Cruces and El Paso areas. Additionally, the lower groundwater table due to over-pumping of the semi-arid alluvial aquifers may greatly increase infiltration of the Rio Grande water into alluvial sediments (Szynkiewicz et al., 2011; Sheng, 2013) and, thus, decrease ion fluxes as observed in Locations 16 through 20 in April 2010. Nevertheless, in November 2009 the considerable increases of ion fluxes were observed in the Indio Research Station (Loc. 21) (Fig. 3A). Given that Indio is located in a rural region of the Chihuahuan Desert with no significant agriculture activity, we conclude that particularly in November 2009 the local increases of ion fluxes might have been more controlled by local groundwater recharge into the Rio Grande. The latter is likely intensified after summer monsoon which is the main source of recharge in this portion of Chihuahua Desert.

\section{2. $\mathrm{S}$ and $\mathrm{O}$ isotope compositions of dissolved $\mathrm{SO}_{4}$}

\subsubsection{Sulfide-derived $\mathrm{SO}_{4}$}

$\mathrm{SO}_{4}$ is one of the major ions dissolved in the Rio Grande surface water, reaching high concentrations $(\sim 500-750 \mathrm{mg} / \mathrm{L})$ in southern New Mexico and west Texas (Suppl. Tab. 1, Fig. 2B). Except for Location 2 at Alamosa in southern Colorado, we observed low $\delta^{34} \mathrm{~S}$ of -3.7 to $-0.2 \%$ in the upstream Rio Grande (Loc. 1 to 10; Fig. 4A). This implies a higher $\mathrm{SO}_{4}$ contribution from weathering of bedrock sulfides which usually show distinctive, negative $\delta^{34} \mathrm{~S}(<0 \%$ ) in terrestrial rocks (e.g., Krouse and Grinenko; 1991; Clark and Fritz, 1997; Coplen et al., 2002).

In southern Colorado and northern New Mexico (Loc. 1-5), the Tertiary hydrothermal sulfides of the San Juan and Sangre de Cristo Mountains show low $\delta^{34} \mathrm{~S}$ of -8.9 to +2.7 \%o (Tab. 2; Nordstrom et al., 2007; Campbell and Lueth, 2008). Accordingly, the $\delta^{34} \mathrm{~S}$ values of the Rio Grande headwaters (-5.0 to $+0.6 \%$; Loc. $1-5,22-27)$ and in the northern tributaries of the Rio Hondo and the Red River $(-2.5$ to +1.3 \%; Loc. 4, 28-32) were consistent with $\mathrm{SO}_{4}$ derived from sulfide weathering. In contrast, the biogenic sulfides from the Cretaceous shales/sandstones/coals of the Rio Chama watershed (Loc. 33-35) show distinctive negative $\delta^{34} \mathrm{~S}$ values of -22.3 to $-9.5 \%$ (Tab. 2; Szynkiewicz et al. 2014). Therefore, a 
considerable decrease of $\delta^{34} \mathrm{~S}$ was observed in the Rio Grande (from +1.3 to $-3.7 \%$; Fig. $4 \mathrm{~A}$ ) at the confluence with the Rio Chama (Loc. 7), which carried significant loads of sulfide-derived $\mathrm{SO}_{4}$ (Fig. 3A $4 A)$. Generally, the Rio Chama contributes substantial fluxes of $\mathrm{SO}_{4}$ with low $\delta^{34} \mathrm{~S}(-16.8$ to $-1.2 \%$; Fig. 6) to the Rio Grande because of the increased water releases by three upstream reservoirs Heron, El Vado and Abiquiu, currently belonging to the San Juan-Rio Chama Water Project (see Chapter 2 for more details). In November 2009 and April 2010 the $\mathrm{SO}_{4}$ fluxes of the Rio Chama were high and comprised $\sim 34 \%$ and $60 \%$, respectively, of the total $\mathrm{SO}_{4}$ flux measured in the Rio Grande below the confluence.

Nevertheless, according to $\delta^{34} \mathrm{~S}$ evidence (Fig. 4A) the sulfide-derived $\mathrm{SO}_{4}$ fluxes varied greatly locally and were controlled by changes in bedrock composition and to some degree by river diversions related to the San Juan-Rio Chama Water Project. For example, the $\delta^{34} \mathrm{~S}$ in the El Vado reservoir of the Rio Chama (Loc. 35) ranged from -16.8 to -16.3 \% (Fig. 6). In this area, Cretaceous shales/sandstones are the major bedrock that crops out and distinctive sulfide weathering is locally manifested by surface accumulations of sulfate-rich salts with low $\delta^{34} \mathrm{~S}$ (on average -18.0 ; Tab. 2). In contrast, the $\delta^{34} \mathrm{~S}$ was higher (-14.2 to $-7.8 \%$ ) in the upstream Heron reservoir (Loc. 33), located closer to the Azotea tunnel outlet transporting water from the adjacent San Juan River watershed for the San Juan-Rio Chama Water Project (above Loc. 33 on Fig. 1). We linked these $\delta^{34} \mathrm{~S}$ to higher $\mathrm{SO}_{4}$ contributions from the Tertiary hydrothermal sulfide-rich alterations of the San Juan Mountains, which show higher $\delta^{34} \mathrm{~S}$ of -6.9 to +2.5 \%o (Nordstrom et al., 2007) compared to the sedimentary sulfides of the Rio Chama watershed with significantly lower $\delta^{34} \mathrm{~S}$ of -22.3 to $-9.5 \%$ (Tab. 2).

The $\delta^{18} \mathrm{O}$ of $\mathrm{SO}_{4}$ in the Rio Grande was useful in understanding the $\mathrm{SO}_{4}$ contributions from acid rock drainage. Generally, the sulfide-derived $\mathrm{SO}_{4}$ from sulfide-rich rock and abandoned mining sites show a tendency to have lower $\delta^{18} \mathrm{O}$ relative to $\mathrm{SO}_{4}$ derived from sulfide weathering in non-mining areas (e.g., Nordstrom et al., 2007). This is a result of greater utilization of oxygen from water molecules $\left(\delta^{18} \mathrm{O}<-5\right.$ \%) rather than molecular oxygen from air $\left(\delta^{18} \mathrm{O}=+25.3 \%\right.$ ) during sulfide oxidation to $\mathrm{SO}_{4}$ in mining sites, controlled by high ferric iron/sulfide surface ratios (e.g., Heidel and Tichomirowa, 2011). In the upstream Rio Grande (Loc. 1-5) and its tributaries (e.g., Red River, Loc. 28-32), we observed significantly lower $\delta^{18} \mathrm{O}$ of $\mathrm{SO}_{4}(-7.1$ to $-0.7 \%$ ) compared to the upstream Rio Chama (-0.6 to $+0.6 \%$ ) (Fig. 5). We infer that this mainly resulted from higher contributions of sulfide-derived $\mathrm{SO}_{4}$ from mining and natural acid rock drainage (Fig. 5), common features in the Rio Grande recharge areas of southern Colorado and northern New Mexico (Locations 1 through 5; Fig. 1).

\subsubsection{Sulfate-derived $\mathrm{SO}_{4}$}

In addition to sulfide-derived $\mathrm{SO}_{4}$, we identified important $\mathrm{SO}_{4}$ contributions from the dissolution of bedrock sulfate minerals because the $\delta^{34} \mathrm{~S}_{\text {of }} \mathrm{SO}_{4}$ in the Rio Grande upstream locations $(-3.7$ to $+1.9 \%$; 
Fig. 4A) was always higher compared to the average $\delta^{34} \mathrm{~S}$ of major sulfide end members (e.g., Tertiary -3 $\%$; Cretaceous -18 \%; Tab. 2). In southern Colorado and northern New Mexico, contributions from sulfate-derived $\mathrm{SO}_{4}$ to the Rio Grande were likely sourced by the dissolution of Tertiary hydrothermal gypsum and anhydrite $(+6.6$ to $+18.0 \%$ ) which are common in ore mineralization of this area (Tab. 2 ; Nordstrom et al., 2007; Campbell and Lueth, et al. 2008). In contrast, the dissolution of Jurassic marine gypsum (+15.1 to $+17.7 \%$; Kirkland et al., 1995) was more important in central New Mexico. For example, we observed significant increases of $\delta^{34} \mathrm{~S}$ in the downstream Rio Chama, from -16.3 to $-2.8 \%$ (Fig. 6), reflecting the increasing abundance of Jurassic evaporites. Similar increases of $\delta^{34} \mathrm{~S}$, from -6.3 to $+5.8 \%$ (Suppl. Tab. 1), were also observed further downstream in the Rio Puerco tributary (Loc. 39-40) where Paleozoic evaporites with high $\delta^{34} \mathrm{~S}$ of $>+10 \%$ are more abundant in the bedrock.

Paleozoic and Mesozoic sedimentary formations become more abundant in the bedrock of central/south New Mexico and west Texas. Consequently, the regional change of bedrock geology from crystalline/volcanic units in the north (Loc. 1 to 6 ) to the sedimentary formations with marine gypsum/anhydrite in the south (Loc. 7 to 21 ) was reflected by increasing $\delta^{34} \mathrm{~S}$ and $\delta^{18} \mathrm{O}$ in the groundwater of the Rio Grande Valley (Fig. 5). Consistent with the isotope composition of the Paleozoic/Mesozoic evaporites (Tab. 2), the $\delta^{34} \mathrm{~S}$ and $\delta^{18} \mathrm{O}$ values of +7.9 to $+10.5 \%$ and +7.7 to $+11.2 \%$, respectively, were observed in the aquifer water from the alluvial basins in Socorro (Loc. 73-76), Mesilla (Loc. 78-84) and the Hueco-Bolson (Loc. 85-88). Conversely, the geothermal water (Loc. 77) showed considerably lower $\delta^{18} \mathrm{O}$ of +3.5 to $+7.8 \%$ compared to the higher $\delta^{34} \mathrm{~S}$ of +7.8 to $+10.1 \%$ (Fig. 5 , Suppl. Tab. 1) and higher $\delta^{18} \mathrm{O}$ of sedimentary gypsum in local Paleozoic formations ( +11 to $+12 \%$; Lueth et al., 2005). The $\mathrm{SO}_{4}$ is a stable molecule in room temperature; however, at higher temperatures $\mathrm{SO}_{4}$ starts exchanging its oxygen with water oxygen (e.g., Craig, 1963). Because precipitation with negative $\delta^{18} \mathrm{O}$ of -11 to $-9 \%$ is a primary recharge for groundwater in New Mexico (Szynkiewicz et al. 2011), the observed lowering of $\delta^{18} \mathrm{O}$ of $\mathrm{SO}_{4}$ in geothermal groundwater is likely reflective of the oxygen isotope exchange between $\mathrm{SO}_{4}$ and water of meteoric origin. Generally, the $\delta^{18} \mathrm{O}$ of the studied groundwater samples in the semi-arid southern locations (e.g., Loc. 74-76, 87-88) always plotted between the $\delta^{18} \mathrm{O}$ of high- and lowtemperature saline end members (Locs. 77 and 85 on Fig. 5, respectively). Therefore, we imply that geothermal activity of the Rio Grande rift, common in southern locations 13 through 20 (e.g., Witcher et al., 2004), is likely important in lowering of the $\delta^{18} \mathrm{O}$ in the $\mathrm{SO}_{4}$ of the aquifer (basinal) groundwater.

In spite of significant increases of $\delta^{34} \mathrm{~S}$ and $\delta^{18} \mathrm{O}$ in all of the studied groundwater (Fig. 5) following the regional increase of sulfate-derived $\mathrm{SO}_{4}$ from sedimentary rocks, the surface water of the Rio Grande showed considerably smaller isotopic increases ( 1-2 \%o; Fig. 4, 5) in southern locations (Loc. 16-21). This suggests small contributions of sulfate-derived $\mathrm{SO}_{4}$ via surface runoff during the summer monsoon and limited groundwater recharge to the Rio Grande in the southern study locations. Most likely, the latter 
is due to prevailing dry conditions, the intense pumping for irrigation and lowering of the groundwater table in the Rio Grande Valley (Szynkiewicz et al., 2011; Sheng, 2013). The infiltration of the Rio Grande surface water into alluvial sediments leads to decreases in the $\delta^{34} \mathrm{~S}$ in groundwater, particularly in the shallow alluvial aquifers (Szynkiewicz et al., 2011)

Interestingly, we did not find strong evidence for important $\mathrm{SO}_{4}$ contributions from the municipal waste water effluents (Fig. 4AB). These are important artificial tributaries to the semi-arid Rio Grande in southern New Mexico and west Texas, particularly during the fall and winter when stream flows are reduced due to less water releases from the Elephant Butte reservoir. While the $\delta^{34} \mathrm{~S}$ of all of the studied waste water effluents increased southward $(+1.5$ to $+7.1 \%$; Fig. $4 \mathrm{~A})$ following increasing contributions of sulfate-derived $\mathrm{SO}_{4}$ from municipal groundwater, the $\delta^{18} \mathrm{O}$ remained relatively low $(+1.7$ to $+3.0 \%$ ) compared to the Rio Grande (>+6 \%; Fig. 4B) and bedrock $\mathrm{SO}_{4}(\sim+10 \%)$. Instead, we noticed that there is likely more exchange of $\mathrm{SO}_{4}$ between the river and agricultural drains (via direct drain inflow and/or irrigation recharge) because the studied drains showed similar small increases of $\delta^{34} \mathrm{~S}$ and $\delta^{18} \mathrm{O}$ as the Rio Grande. Most likely, this resulted from noticeably higher $\mathrm{SO}_{4}$ concentrations in agricultural drains (average $395 \mathrm{mg} / \mathrm{L}$ ) compared to the waste effluents (average $195 \mathrm{mg} / \mathrm{L}$ ).

In all seasons we observed considerably higher $\delta^{34} \mathrm{~S}$ of +5.4 to $+8.0 \%$ and $\delta^{18} \mathrm{O}$ of +2.7 to $+4.9 \%$ in Alamosa in southern Colorado (Loc. 2) (Fig. 4AB). This increase can be explained by the dissolution of local evaporites; however, they are not common in this region. Alamosa is located in the center of the San Luis Valley Irrigation District, which uses the Rio Grande water for flood irrigation. Therefore, we imply that small contribution of $\mathrm{SO}_{4}$ with higher $\delta^{34} \mathrm{~S}$ and $\delta^{18} \mathrm{O}$ might have come from local anthropogenic sources such as gypsum fertilizers $\left(\delta^{34} \mathrm{~S}+9.3\right.$ to $13.6 \%$; $\delta^{18} \mathrm{O}+16.9$ to $+17.1 \%$; Szynkiewicz et al. - Part 2). Alternatively, additional $\mathrm{SO}_{4}$ might have been contributed by dissolution of Pleistocene lake sediments which crop out in the center of San Luis Valley and may contain some sulfate minerals from evaporation of lake water. In the total $\mathrm{S}$ budget of the Rio Grande, however, the $\mathrm{SO}_{4}$ flux at Alamosa (2.5 and 3.4 metric tons/day in Nov 2009 and Apr 2010, respectively) was insignificant, comprising $\sim 1-3 \%$ of the total $\mathrm{SO}_{4}$ flux measured in the Rio Grande recharge area (Fig. 3AB).

\subsubsection{Other $\mathrm{SO}_{4}$ sources and microbial processes}

Although atmospheric deposition might be another important source of $\mathrm{SO}_{4}$ in hydrological system (e.g., Mayer et al., 2005b; Shanley et al., 2005), we were unable to assess its contribution in the studied water samples because the $\delta^{34} \mathrm{~S}$ of atmospheric $\mathrm{SO}_{4}$ in New Mexico ( $+6.5 \%$ overlaps with the evaporite $\mathrm{SO}_{4}$ end members $(+6.6$ to $+18.0 \%$ ). In New Mexico, however, these fluxes are significantly smaller (median 2-4\%) compared to the total bedrock contribution (Szynkiewicz et al., 2012). Negligible 
contributions of atmospheric $\mathrm{SO}_{4}$ to the Rio Grande are also supported by the overall responses of the $\delta^{34} \mathrm{~S}$ and $\delta^{18} \mathrm{O}$ in the studied water samples to regional changes of bedrock geology (Fig. 5).

Additionally, in the studied Rio Grande samples we did not observe any important changes of $\delta^{34} \mathrm{~S}$ and $\delta^{18} \mathrm{O}$ related to microbial processes. Dissimilatory microbial $\mathrm{SO}_{4}$ reduction causes substantial increases of $\delta^{34} \mathrm{~S}$ and $\delta^{18} \mathrm{O}$ that are accompanied by a decrease of $\mathrm{SO}_{4}$ concentration (e.g., Strebel et al., 1990; Spence et al., 2001; Canfield, 2001). Given that the southward increases of $\delta^{34} \mathrm{~S}$ and $\delta^{18} \mathrm{O}$ in the Rio Grande were always accompanied by relatively high $\mathrm{SO}_{4}$ concentrations (100-750 mg/L), we conclude that dissimilatory microbial $\mathrm{SO}_{4}$ reduction had a minor or negligible impact on the isotope composition of the Rio Grande $\mathrm{SO}_{4}$. We do suggest, however, that in all of the studied waste water treatment effluents (Fig. 4B) the considerably lower $\delta^{18} \mathrm{O}$ of $\mathrm{SO}_{4}(+1.7$ to $+3.0 \%$ ) compared to the Rio Grande and groundwater ( +3.5 to $+11.2 \%$ ) might be in part related to microbial processes during the treatment. We speculate that this process is similar to what has been observed in soils (e.g., Mayer et al., 1995; Shanley et al., 2005; Yuan and Mayer, 2012). Assimilatory microbial $\mathrm{SO}_{4}$ reduction and re-oxidation in soils usually lead to lowering of initial $\delta^{18} \mathrm{O}$ in $\mathrm{SO}_{4}$ because some oxygen atoms in the $\mathrm{SO}_{4}$ are replaced by oxygen from soil water with negative $\delta^{18} \mathrm{O}$. These processes typically have only a small effect on the $\delta^{34} \mathrm{~S}$ values of $\mathrm{SO}_{4}$ unless dissimilatory bacterial sulfate reduction occurs (Mitchell et al., 1998). Accordingly, in the studied waste water samples the $\delta^{34} \mathrm{~S}$ was always higher compared to the Rio Grande (Fig. 4A), which is a reflection of the increasing contribution of aquifer water (used for municipal supplies) with higher $\delta^{34} \mathrm{~S}$ in downstream locations (Fig. 5).

\subsection{Sulfur isotope mass balance constraints}

Generally, we observed decreases in $\delta^{34} \mathrm{~S}$ with increasing $\mathrm{SO}_{4}$ concentrations for the high-mountain recharge areas of the Rio Grande in southern Colorado and northern New Mexico (Loc. 1-9; Fig. 7A). This suggests mixing between two major $\mathrm{SO}_{4}$ end-members; (1) sulfide weathering (low $\delta^{34} \mathrm{~S}$ ) and (2) the dissolution of bedrock sulfate minerals (high $\delta^{34} \mathrm{~S}$; see Chapter 5.2 for more details). Similarly, the $\delta^{34} \mathrm{~S}$ decreased versus $\mathrm{SO}_{4}$ flux in both the recharge areas and the semi-arid reach of the Rio Grande (Fig. 7B). While the $\mathrm{SO}_{4}$ fluxes were controlled to a large extent by water releases in several upstream reservoirs (Fig. 1), we infer that these fluxes are largely overestimated compared to what would be observed under pristine condition.

In order to calculate the sulfide- versus evaporite-derived $\mathrm{SO}_{4}$ contribution in the main recharge areas of the Rio Grande watershed, we used S isotope mass balance constraint as follows:

$\delta^{34} \mathrm{~S}_{\text {stream }}=\left(\mathrm{r} \times \delta^{34} \mathrm{~S}_{\text {sulfide }}\right)+\left([1-\mathrm{r}] \times \delta^{34} \mathrm{~S}_{\text {evaporite }}\right)$ 
where $\mathrm{r}$ represents the fraction contribution of the sulfide-derived $\mathrm{SO}_{4}$ isotopic end-member. In these calculations, we considered four locations along the Rio Grande (Locs. 1, 5, 7, 10) and three tributaries (Locs. 32, 38, 40) that we had sufficient information about $\delta^{34} \mathrm{~S}$ of major sulfide- and sulfate-derived $\mathrm{SO}_{4}$ bedrock sources. In Table 2 and 3 , we presented the variations of $\delta^{34} S$ in the Tertiary and Mesozoic/Paleozoic S-rich endmembers used in our mas balance calculations. In many cases, the ranges of $\delta^{34} \mathrm{~S}$ in the sulfide endmembers of volcanic and sedimentary bedrock greatly overlap, as do the $\delta^{34} \mathrm{~S}$ of sulfate endmembers (Tab. 2). Therefore, on a regional scale our $\mathrm{S}$ isotope mass balance constraints serve as a good approximation for the total sulfide- and sulfate-derived $\mathrm{SO}_{4}$ fluxes coming from oxidation and dissolution of both volcanic and sedimentary rocks.

The $\mathrm{S}$ isotope mass balance data obtained using this approach, are compiled in Table 3. Our mass balance results showed that the sulfide-derived $\mathrm{SO}_{4}$ fluxes in the Rio Grande and its tributaries significantly decreased downstream (Tab. 3; Fig. 8) as sulfate sources derived from sedimentary marine gypsum/anhydrite in bedrock became more important. Overall, the average sulfide-derived $\mathrm{SO}_{4}$ flux accounted for 83-94\% of the total $\mathrm{SO}_{4}$ flux in the upstream Rio Grande (Loc. 1, 5) and decreased to 45$51 \%$ in central New Mexico because of higher contributions of sulfate-derived $\mathrm{SO}_{4}$ (Loc. 7, 10). This modeling, however, was accompanied by relatively large uncertainties because of the variation of $\delta^{34} \mathrm{~S}$ in the major $\mathrm{SO}_{4}$ end-members. Uncertainty in the calculations was usually within $\pm 10-20 \%$ but in two locations (5 and 32), where the variation of $\delta^{34} \mathrm{~S}$ in each $\mathrm{SO}_{4}$ end-member was large (e.g., hydrothermal deposits in the Red River Valley; Tab. 2), the uncertainty accounted for $\pm 32-33 \%$ (Tab. 3).

\subsection{Factors controlling sulfide weathering}

Previous studies have suggested that sulfide-derived $\mathrm{SO}_{4}$ fluxes are controlled by high relief and active tectonics causing frequent earthquakes, landslides and rock shattering (e.g., Spence and Telmer, 2005; Das et al., 2012). These physical processes are important in increasing erosion rates, exposing fresh sulfide surfaces, and releasing minor/trace sulfides for chemical weathering with atmospheric $\mathrm{O}_{2}($ Berner and Berner, 1996; Beaulien et al., 2011). The sulfide oxidation rate and the ability to generate $\mathrm{H}_{2} \mathrm{SO}_{4}$ is directly proportional to the exposed surface area of sulfide minerals (Rimstidt and Vaughan, 2003) and surface areas increase as grain sizes are reduced via physical processing. Additionally, intense rainfall and polar conditions, which increase freeze-thaw activity, have been identified as important in increasing sulfide weathering rates (Wadham et al., 1998; Anderson et al., 2000; Spence and Telmer, 2005; Das et al., 2012).

In our study area, significantly higher sulfide-derived $\mathrm{SO}_{4}$ fluxes were observed in Apr 2010 during the spring snowmelt as compared to baseflow conditions during Nov 2009 (Fig. 7B). Snowmelt in highmountain areas of southern Colorado and northern New Mexico contribute the majority of recharge to the 
Rio Grande. Therefore, physical erosion on steep mountain slopes is likely an important factor increasing the riverine sulfide-derived $\mathrm{SO}_{4}$. Additionally, we speculate that winter conditions may accelerate sulfide oxidation because of long-term snow cover on high elevations, repeating cycles of partial snow melt, and high surface area of ice/water-rock interaction in surface and near-surface environments. All of these increase accumulation of sulfide weathering products over the winter season and, thus, their greater leaching during snowmelt.

We infer that elevated concentrations of bedrock sulfide might also be partly responsible for increases of sulfide-derived $\mathrm{SO}_{4}$ in the upstream Rio Grande. For example, the lower $\delta^{18} \mathrm{O}$ of $\mathrm{SO}_{4}$ implies that inflows of acid rock drainage in the upstream Rio Grande were important (Fig. 5). Accordingly, elevated sulfide concentrations (up to 2-5\%) can be found on the mine tailings and natural scarps in the San Juan Mountains (Loc. 22-27) and in the Red River Valley (Loc. 28-32) (e.g., Nordstrom et al., 2007; Campbell and Lueth, 2008). Additionally, higher sulfide contents have been reported in the Cretaceous sedimentary formations (up to $2.3 \mathrm{wt} \%$; Hoffman, 1991) in central New Mexico. This, in turn, is in agreement with the observed negative $\delta^{34} \mathrm{~S}_{\text {of }} \mathrm{SO}_{4}(-16.8$ to $-6.3 \%)$ in the upper reaches of the Rio Chama and Rio Puerco tributaries where Cretaceous rocks are the major bedrock.

Other investigators (e.g., Spence and Telmer, 2005; Das et al., 2012) suggested that intense rainfall and increased snow/ice-rock interaction enhance contributions of sulfide-derived $\mathrm{SO}_{4}$ into hydrological systems. Nevertheless, in the Rio Grande and its tributaries we did not find an important relationship between sulfide-derived $\mathrm{SO}_{4}$ flux and climate. In April 2010, these fluxes were comparably high both in wetter high-mountain and semi-arid areas (Fig. 7B). The highest $\mathrm{SO}_{4}$ flux ( $\sim 600$ metric tons/day) with negative $\delta^{34} \mathrm{~S}(-1.5 \%$ ) was observed in the semi-arid central New Mexico (Loc. 10), below the confluence of the Rio Puerco with the Rio Grande. The Rio Puerco is an intermittent stream controlled seasonally by increased sulfide-derived $\mathrm{SO}_{4}$ fluxes $\left(\delta^{34} \mathrm{~S}\right.$ of -8.5 to $-0.8 \%$ ) due to elevated bedrock sulfide contents in Cretaceous formations and high accumulation of surficial (secondary) salts (e.g., MgCa-Na sulfates) in the stream channel (Szynkiewicz et al., 2014). The repeating cycles of salt dissolution and precipitation in the stream channel increase surface accumulation of sulfate-rich salts with low $\delta^{34} \mathrm{~S}$ (36.0 to $-8.5 \%$ ), which was originally derived from the oxidation of bedrock sulfides present in Cretaceous bedrock. Therefore, recycling of those salts during episodic water activity is important in increasing sulfide-derived $\mathrm{SO}_{4}$ fluxes in the semi-arid Rio Puerco and consequently in the Rio Grande.

\section{Conclusions and Implications}

We identified two major $\mathrm{SO}_{4}$ sources in the Rio Grande and its tributaries: (1) sulfide weathering and (2) dissolution of primary sulfate minerals present in the Precambrian/Tertiary volcanic rocks and in the Paleozoic/Mesozoic sedimentary formations. When compared to the sulfate/evaporite-derived $\mathrm{SO}_{4}$, the 
highest sulfide-derived $\mathrm{SO}_{4}$ fluxes were measured in upstream high mountain-areas with more volcanic rocks on the surface $(83-94 \pm 20 \%)$. Generally, the increase of sedimentary evaporites in the regional bedrock involved the decrease of sulfide-derived $\mathrm{SO}_{4}(45-51 \pm 20 \%)$ to the Rio Grande in central New Mexico.

Sulfide bedrock content appears to be partly important in increasing sulfide-derived $\mathrm{SO}_{4}$ fluxes in the upstream Rio Grande where acid rock drainage in volcanic terrains and elevated sulfide contents in the Cretaceous sedimentary formations are common.

Generally, sulfides are important constituents of Earth's sedimentary rocks $\left(6 \times 10^{21} \mathrm{~g} \mathrm{~S}\right)$ and exceed the mass of S accumulated in the marine evaporites $\left(3 \times 10^{21} \mathrm{~g} \mathrm{~S}\right)$ (Bottrell and Newton, 2006). Given that sulfides are also common minerals in various crystalline and volcanic rocks, the high proportions of sulfides in terrestrial rocks are likely reflected in substantial sulfide-derived $\mathrm{SO}_{4}$ fluxes in modern river systems across the world (Tab. 1). This observation implies that there may need to be a re-budgeting or fine tuning of the influence of sulfide weathering on atmospheric $\mathrm{O}_{2}$ and $\mathrm{CO}_{2}$ concentrations over long time-scales (Eqs. 1-3). Future studies focused on linking bedrock sulfide contents to the sulfide-derived $\mathrm{SO}_{4}$ fluxes would help to better understand the global sulfur cycle related to sulfide weathering. Consequently, this could help in better predictions and modeling of how historical sulfide weathering affected the concentrations of atmospheric $\mathrm{O}_{2}$ and $\mathrm{CO}_{2}$ over geological time scales.

\section{Acknowledgements}

This study was supported by a State of Texas Norman Hackerman grant and NSF grant 0838120 (D. Borrok), and partially by grants from UTEP URI 14-6485-4651 (A. Szynkiewicz). G. Skrzypek was supported by a Future Fellowship from the Australian Research Council (FT110100352). We greatly thank to the UTEP's students Dennise Drury, Nicole Kyger, Susan Aranda, Ana Lu Gutierrez, Ian Cappelle, and to Ben Linhoff and Patrick Longmire from Los Alamos National Laboratory for the field/lab assistance and to Ben Underwood from Indiana University for assistance with sulfur isotope analysis. Vanessa Lougheed provided the seasonal Rio Grande samples from the UTEP's Indio Research Station and Dennis Powers gave access to his wells in southern Mesilla basin. The discussions with Scott Anderholm, Malynda Cappelle, Talon Newton, Dave Love, Joel Gilbert, John Hawley, Rip Langford, Zhuping Sheng, John Sorrell, Cody Walker and the participation of first author in the Rio Grande Coalition meetings significantly helped in the planning of sampling strategy in the Rio Grande region. The field assistance of the Albuquerque Waste Water Treatment Plant, El Paso Desalination Plant, Bosque del Apache Wildlife Refuge, and the well owners from Espanola basin, Truth or Consequences and Isleta Pueblo is also greatly appreciated.

\section{References}

Abu-Jaber, N., 2001. Geochemical evolution and recharge of the shallow aquifers at Tulul al Asagif, NE Jordan. Environ. Geol. 41, 372-383.

Andersen, M.S., Larsen, F., Postma, D., 2001. Pyrite oxidation in unsaturated aquifer sediments: reaction stoichiometry and rate of oxidation. Environmental Science and Technology 35, 4074-4079. 
Anderson, S.P., Drever, J.I., Frost, C.D., Holden, P., 2000. Chemical weathering in the foreland of a retreating glacier. Geochim. Cosmochim. Acta 64, 1173-1189.

Anning, D.W., Bauch, N.J., Gerner, S.J., Flynn, M.E., Hamlin, S.N., Moore, S.J., Schaefer, D.H., Anderholm, S.K., Spangler, L.E., 2007. dissolved solids in basin-fill aquifers and streams in the southwestern United States. U.S. Geological survey Scientific Investigations Report 2006-5315, 336 p.

Balci, N., Shanks III, W.C., Mayer, B., Mandernack, K.W., 2013. Oxygen and sulfur isotope systematics of sulfate produced by bacterial and abiotic oxidation of pyrite. Geochim. Cosmochim. Acta 71, 3796-3811.

Berner E.K., and Berner R.A. (1996) Global Environment: Water, Air, and Geochemical Cycles. Printice Hall Inc., Simon \& Schuster/A Viacom Company, Upper Saddle River, New Jersey 07458.

Berner, R.A., Lasaga, A.C., Garrels, R.M., 1983. The carbonate-silicate geochemical cycle and its effect on atmospheric carbon dioxide over the past 100 million years. Am. J. Sci. 283, 641-683.

Bottrell, S.H., Newton, R.J., 2006. Reconstruction of changes in global sulfur cycling from marine sulfate isotopes. Earth-Sci. Rev. 75, 59-83.

Bottrell, S.H., Tranter, M., 2002. Sulphide oxidation under partially anoxic conditions at the bed of the Haut Glacier d'Arolla, Switzerland. Hydrological Processes 16, 2363-2368.

Calmels, D., Gaillardet, J., Brenot, A., France-Lanord, C., 2007. Sustained sulfide oxidation by physical erosion processes in the MacKenzie River basin: Climatic perspectives. Geol. 35, 1003-1006.

Campbell, A.R., Lueth, V.W., 2008. Isotopic and textural discrimination between hypogene, ancient supergene, and modern sulfates at the Questa mine, New Mexico. Appl. Geochem. 23, 308-319.

Canfield, D. E., 2001. Biogeochemistry of sulfur isotopes. In Stable Isotope Geochemistry (eds. J.W. Valley and D.R. Cole). Mineralogical Society of America, Blacksburg, VA, vol. 43, pp. 607-636. Clark, K.I., Fritz P., 1997. Environmental Isotopes in Hydrogeology. Lewis Publishers, New York, pp. 328.

Coplen, T. B., Hopple, J. A., Böhlke, J. K., Peiser, H. S., Rieder, S. E., Krouse, H. R., Rosman, K.J.R., Ding, T., Vocke Jr, R. D., Révész, K. M., Lamberty, A., Taylor, P., Bièvre, D., 2002. Compilation of Minimum and Maximum Isotope Ratios of Selected Elements in Naturally Occurring Terrestrial Materials and Reagents. U.S. Geological Survey Water-Resources Investigation Report 01-4222.

Craig, H., 1963. The isotopic geochemistry of water and carbon in geothermal areas. In: Nuclear geology in geothermal areas (Ed. E. Tongiorgi), pp. 17-53. Pisa, Italy: Consiglio Nazionale della Ricerche, Laboratorio de Geologia Nucleare.

Das, A., Chung, C-H., You, C-F., 2012. Disproportionately high rates of sulfide oxidation from mountainous river basins of Taiwan orogeny: Sulfur isotope evidence. Geophys. Res. Lett. 39, L12404, doi: 10.1029/2012GL051549.

Ellis, S.R., Levings, G.w., Carter, L.F., Richey, S.F., Radel, M.J., 1993. Rio Grande Valley, Colorado, New Mexico, and Texas. J. Amer. Wat. Res. Assoc. 29, 617-648.

Eastoe, C.J., Hibbs, B.J., Olivas, A.G., Hogan, J.F., Hawley, J., Hutchison, w.R., 2008. Isotopes in the Hueco Bolson aquifer, Texas (USA) and Chihuahua (Mexico): local and general implications for recharge sources in alluvial basins. Hydrogeol. J. 16, 737-747.

Fennmore, G.C., Neller, W.C., Favis, A., 1998. Modeling pyrite oxidation in arid environments. Environ. Sci. Technol. 32, 2680-2687.

François, L.M., Walker, J.C.G., 1992. Modelling the Phanerozoic carbon cycle and climate: constraints from the ${ }^{87} \mathrm{Sr} /{ }^{86} \mathrm{Sr}$ isotopic ratio of seawater. American Journal of Science, 292, p. 81-135. 
Heidel, C., Tichomirowa, M., 2011. The isotopic composition of sulfate from anaerobic and low oxygen pyrite oxidation experiments with ferric iron - New insights into oxidation mechanisms. Chem. Geol. 281, 305-316.

Hercod, D.J., Brady, P.V., Gregory, R.T., 1998. Catchment-scale coupling between pyrite oxidation and calcite weathering. Chem. Geol. 151, 259-276.

Hoffman, G.K., 1991. Quality assessment of strippable coals in northwest New Mexico: drilling data, chemical and petrographic analyses for the Fruitland, Menefee, Crevasse Canyon, and Moreno Hill Formation. New Mexico Bureau of Mines and Mineral Resources Open File Report 377.

Jia, Z., Luo, W., Xie, J., Pan, Y., Chen, Y., Tang, S., Liu, W., 2011. Salinity dynamics of wetland ditches receiving drainage from irrigated agricultural land in arid and semi-arid regions. Agricul. Wat. Manag. 100, 9-17.

Keller, G.R., and Cather, S.M., 1994. Introduction. In: Keller, G.R., and Cather, S.M., eds., Basins of the Rio Grande rift—structure, stratigraphy, and tectonic setting: Geological Society of America Special Paper 291, p. 1-3.

Keller, G.R., Baldridge, W.S., 1999. The Rio Grande rift: a geological and geophysical overview. Rocky Mountain Geology 34, 121-130.

Kirkland, D.W., Denison, R.E., Evans, R., 1995. Middle Jurassic Todilto Formation of northern New Mexico and southwestern Colorado: Marine or nonmarine? New Mexico Institute of Mining and Technology Bulletin 147, 30-34.

Krouse, H.R., Grinenko, V.A., 1991. Stable Isotopes: Natural and Anthropogenic Sulphur in the Environment. John Willey \& Sons.

Li, S-L., Calmels, D., Han, G., Gaillardet, J., Liu, C-Q., 2008. Sulfuric acid as an agent of carbonate weathering constrained by $\delta^{13} \mathrm{C}_{\mathrm{DIC}}$ : Examples from Southwest China. Earth Planet. Sci. Lett. 270, 189-199.

Lueth, V.W., Rye, R.O., Pters, L., 2005. "Sour gas" hydrothermal jarosite: ancient to modern acid-sulfate mineralization in the southern Rio Grande Rift. Chem. Geol. 215, 339-360.

Mayer, B., Fritz, P., Prietzel, J., Krouse H.R., 1995. The use of stable sulfur and oxygen isotope ratios for interpreting the mobility of sulfate in aerobic forest soils. App. Geochem. 10, 161-173.

Mayer, B., Feger, K.H., Giesemann, A., Jager, H.J., 1995b. Interpretation of sulfur cycling in two catchments in the Black Forest (Germany) using stable sulfur and oxygen isotope data. Biogeochemistry 30, 31-58.

Mitchell, M.J., Krouse, H.R., Mayer, B., Stam, A.C., Zhang, Y., 1998. Use of stable isotopes in evaluating sulfur biogeochemistry of forest ecosystems. In: Kendall C. and McDonnell J.J. (eds.), in Catchment Hydrology. Elsevier, Amsterdam, pp. 489-518.

Mees, F., 2003. Salt mineral distribution patterns in soils of the Otjomongwa pan, Namibia. Catena 54, 425-437.

Nakai, N., Jensen, M.L., 1964. The kinetic isotope effect in the bacterial reduction and oxidation of sulfur. Geochim. et Cosmochim. Acta 28, 1893-1912.

Nordstrom, D.K., Wright, W.G., Mast, M.A., Bove, D.J., and Rye, R.O., 2007. Aqueous-sulfate stable isotopes - A study of mining-affected and undisturbed acidic drainage. In: Church, S.E., von Guerard, P., and Finger, S.E., eds., Integrated Investigations of Environmental Effects of Historical Mining in the Animas River Watershed, San Juan County, Colorado: U.S. Geological Survey Professional Paper 1651, chapter E8, p. 387-416. 
Phillips, F.M., Hogan, J.F., Mills, S.K., Hendrickx, J.M.H., 2003. Environmental tracers applied to quantifying causes of salinity in arid-region rivers: results from the Rio grande, southwestern USA. In: Water Resources Perspectives: evaluation, Management and Policy. (Eds.) Alsharhan, A.s., Wood, W.W.. New York, Elsevier Science, p. 327-334.

Plummer L.N., Bexfield L.M., Anderholm S.K., Sanford W.E., Busenberg E., 2004. Geochemical characterization of groundwater flow in the Santa Fe Group aquifer system, Middle Rio Grande Basin, New Mexico. U.S. Geological Survey Water-Resources Investigations Report 03-4131.

Raab, M., Spiro, B., 1991. Sulfur isotope variations during seawater evaporation with fractional crystallization. Chem. Geol. 86, 323-333.

Rimstidt, J.D., Vaughan, D.J., 2003. Pyrite oxidation: A state-of-the-art assessment of the reaction mechanism. Geochim. Cosmochim. Acta 67, 873-880.

Sanford, W.E., Plummer, L.N., McAda, D.P., Bexfield, L.M., Anderholm, S.K., 2004. Hydrochemical tracers in the middle Rio Grande Basin, USA: 2. Calibration of a groundwater flow model. Hydrogeol. J. 12, 389-407.

Shanley, J.B., Mayer, B., Mitchell, M.J., Michel, R.L., Bailey, S.W., Kendall, C., 2005. Tracing sources of streamwater sulfate during snowmelt using $\mathrm{S}$ and $\mathrm{O}$ isotope ratios of sulfate and ${ }^{35} \mathrm{~S}$ activity. Biogeochemistry 76, 161-185.

Sheng, Z., 2013. Impacts of groundwater pumping and climate variability on groundwater availability in the Rio Grande Basin. Ecosphere 4, 1-25.

Skrzypek, G., 2013. Normalization procedures and reference material selection in stable HCNOS isotope analyses - an overview. Analytical and Bioanalytical Chemistry 405, 2815-2823.

Skrzypek, G., Sadler, R., 2011. A strategy for selection of reference materials in stable oxygen isotope analyses of solid materials. Rapid Commun. Mass Spectrom. 25, 1625-1630.

Spence, J., Telmer, K., 2005. The role of sulfur in chemical weathering and atmospheric $\mathrm{CO}_{2}$ fluxes: Evidence from major ions, $\delta^{13} \mathrm{C}_{\mathrm{DIC}}$ and $\delta^{34} \mathrm{~S}_{\mathrm{SO} 4}$ in rivers of the Canadian Cordillera. Geochim. Cosmochim. Acta 69, 5441-5458.

Spence, M.J., Bottrell, S.H., Thornton, S.F., Lerner, D.N., 2001. Isotopic modelling of the significance of sulphate reduction for phenol attenuation in a polluted aquifer. Journal of Contaminant Hydrology 53, 285-304.

Strebel, O., Böttcher, J., Fritz, P., 1990. Use of isotope fractionation of sulfate-sulfur and sulfate-oxygen to assess bacterial desulfurication in a sandy aquifer. Journal of Hydrology 121, 155-172.

Szynkiewicz, A., Borrok, D.M., Ganjegunte, G.K., Skrzypek, G. Ma, L., Rearick, M., Perkins, P. Isotopic studies of the Upper and Middle Rio Grande. Part 2 - Salt loads and human impacts in south New Mexico and west Texas. Chemical Geology - in review.

Szynkiewicz, A., Borrok, D.M., Vaniman, D.V., 2014. Efflorescence as a source of hydrated sulfate minerals in valley settings on Mars. Earth. Planet. Sci. Let. 393, 14-25.

Szynkiewicz, A., Modelska, M., Buczyński, S., Borrok, D.M., Merrison, J.P., 2013. The polar sulfur cycle in the Werenskioldbreen, Spitsbergen: Possible implications for understanding the deposition of sulfate minerals in the North Polar Region of Mars. Geochim. Cosmochim. Acta 106, 326-343.

Szynkiewicz, A., Newton, B.T., Timmons, S., Borrok, D.M., 2012. The sources and budget for dissolved sulfate in a fractured carbonate aquifer, southern Sacramento Mountains, New Mexico, USA. Appl. Geochem. 27, 1451-14.62.

Szynkiewicz A., Witcher J., Modelska M., Borrok D.B., Pratt L.M., 2011. Anthropogenic sulfate loads in the Rio Grande, New Mexico. Chem. Geol. 283, 194-209. 
Tichomirowa, M., Junghans, M., 2009. Oxygen isotope evidence for sorption of molecular oxygen to pyrite surface sites and incorporation into sulfate in oxidation experiments. Appl. Geochem. 24, 20722092.

Toran, L., Harris, R.F., 1989. Interpretation of sulfur and oxygen isotopes in biological and abiological sulfide oxidation. Geochim. Cosmochim. Acta 53, 2341-2348.

Yuan, F., Mayer, B., 2012. Chemical and isotopic evaluations of sulfur sources and cycling in the Pecos River, New Mexico, USA. Chem. Geol. 291, 13-22.

Yuan, F., Miyamoto, S., 2008. Characteristics of oxygen-18 and deuterium composition in waters from the Pecos River in American Southwest. Chem. Geol. 255, 220-230.

Yuan, F., Miyamoto, S., Anand, S., 2007. Changes in major element hydrochemistry of the Pecos River in the American Southwest since 1935. App. Geochem. 22, 1978-1813.

Yuan, F., Maiyamoto, S., 2005. Dominant process controlling water chemistry of the Pecos River in American southwest. Geophys. Res. Lett. 32, L17406, doi: 10.1029/2005GL023359.

Wadham, J.L., Hodson, A.J., Tranter, M., Dowdeswell, J.A., 1998. The hydrochemistry of meltwaters draining a polythermal-based, high Arctic glacier, south Svalbard: I. The ablation season. Hydrologic. Process. 12, 1825-1849.

Walker, J.C.G., Hays, P.B., Kasting, J.F., 1981. A negative feedback mechanism for the long-term stabilization of earth's surface temperature. J. Geophys. Res. 86, 9776-9782.

Witcher, J.C., King, J.P., Hawley, J.W., Kennedy, J.W., Williams, J., Cleary, M., Bothern, L.R., 2004. Sources of salinity in the Rio Grande and Mesilla Basin groundwater: New Mexico Water Resources Reearch Institute WRRI Technical completion Report No. 330, 168 p.

Vear, A., Curtis, C., 1981. A quantitative evaluation of pyrite weathering. Earth Surface Processes and Landforms 6, 191-198. 
Figure 1. Location map with the surface water and groundwater sampling points. The semi-arid area of Chihuahua Desert begins at Location 3 and continues downstream to location 21. The semi-arid area excludes the high mountain ranges in northern New Mexico (e.g., Sangre de Cristo Mountains, Jemez Mountains). For figure in color, the reader is referred to the web version of this article.

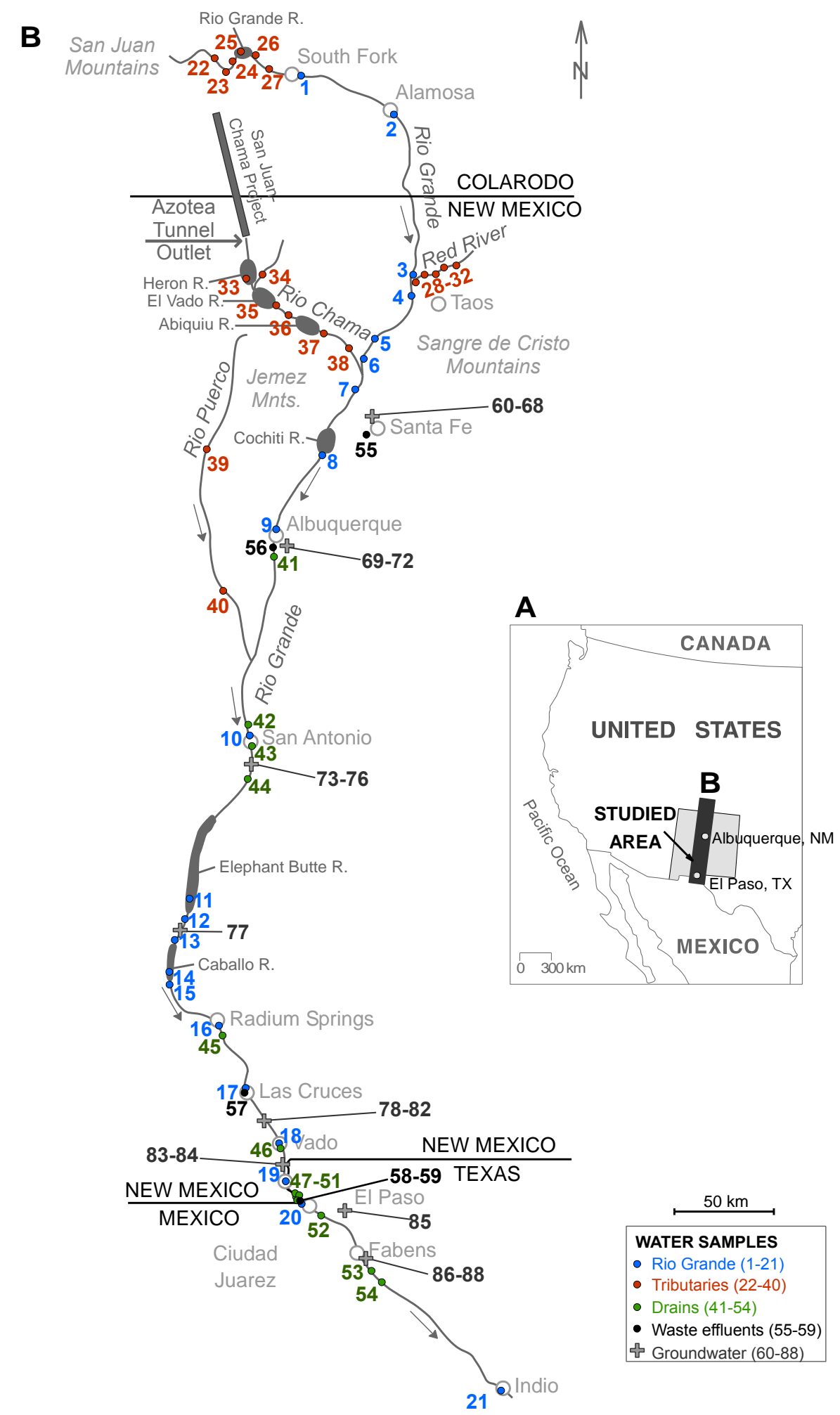


Figure 2. Variations of average (A) electric conductivity, (B) $\mathrm{SO}_{4}, \mathrm{Cl}, \mathrm{HCO}_{3}$ and (C) $\mathrm{Na}, \mathrm{Ca}, \mathrm{K}+\mathrm{Mg}$ concentrations in the Rio Grande, drains and waste water effluents relative to the distance from the Rio Grande headwaters. The reported average is that of samples from the same location collected during different seasons (Suppl. Tab. 1). For ease of illustration the error bars based on differences are not shown. For figure in color, the reader is referred to the web version of this article.
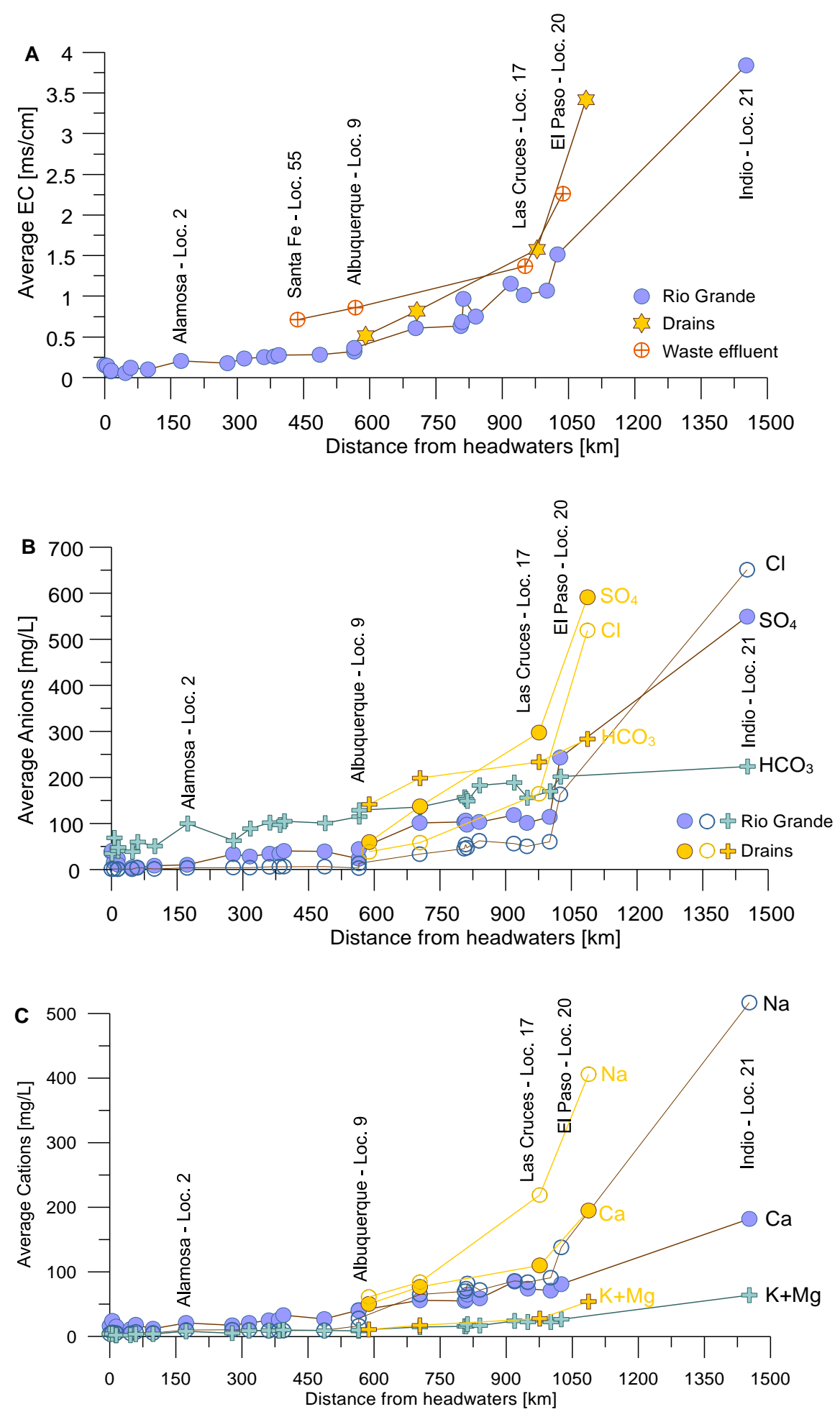
Figure 3. Fluxes of major ions into the Rio Grande in Nov 2009 (non-irrigation season) and in Apr 2010 (irrigation season). Numbers indicate sample locations shown on Figure 1. Note that different Y axis scales were used on A and B for better clarity.
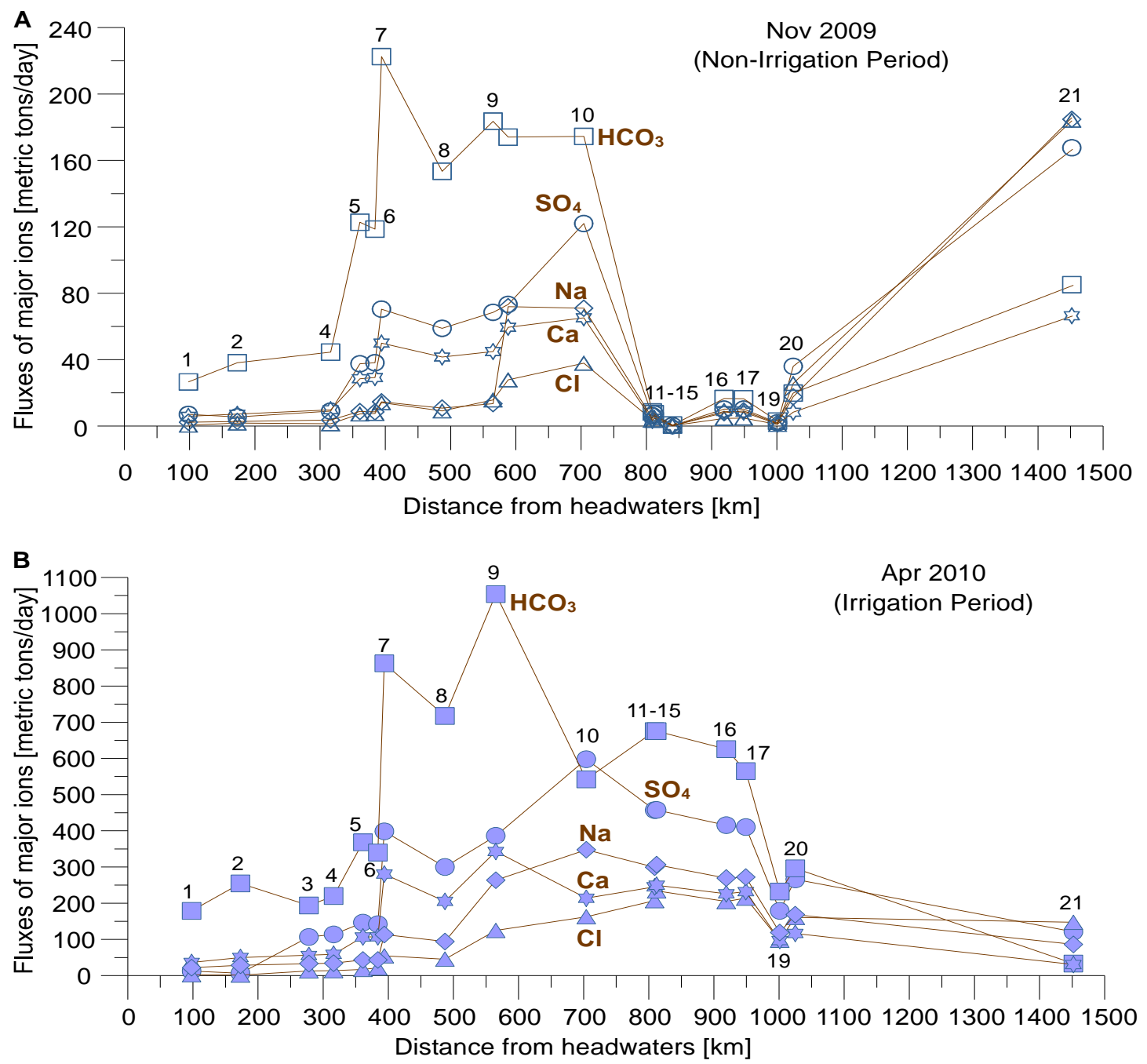
Figure 4. Variations of $\delta^{34} \mathrm{~S}$ and $\delta^{18} \mathrm{O}$ of $\mathrm{SO}_{4}$ in the Rio Grande, agricultural drains and waste water effluentsrelative to the distance from headwaters. Numbers indicate sampling locations shown on Figure 1. The seasonal variations of $\delta^{34} S$ for October 2007, April and November 2008 were adopted from Szynkiewicz et al. (2011). The reported average is that of samples from the same location collected during different seasons (Suppl. Tab. 1). For figure in color, the reader is referred to the web version of this article.
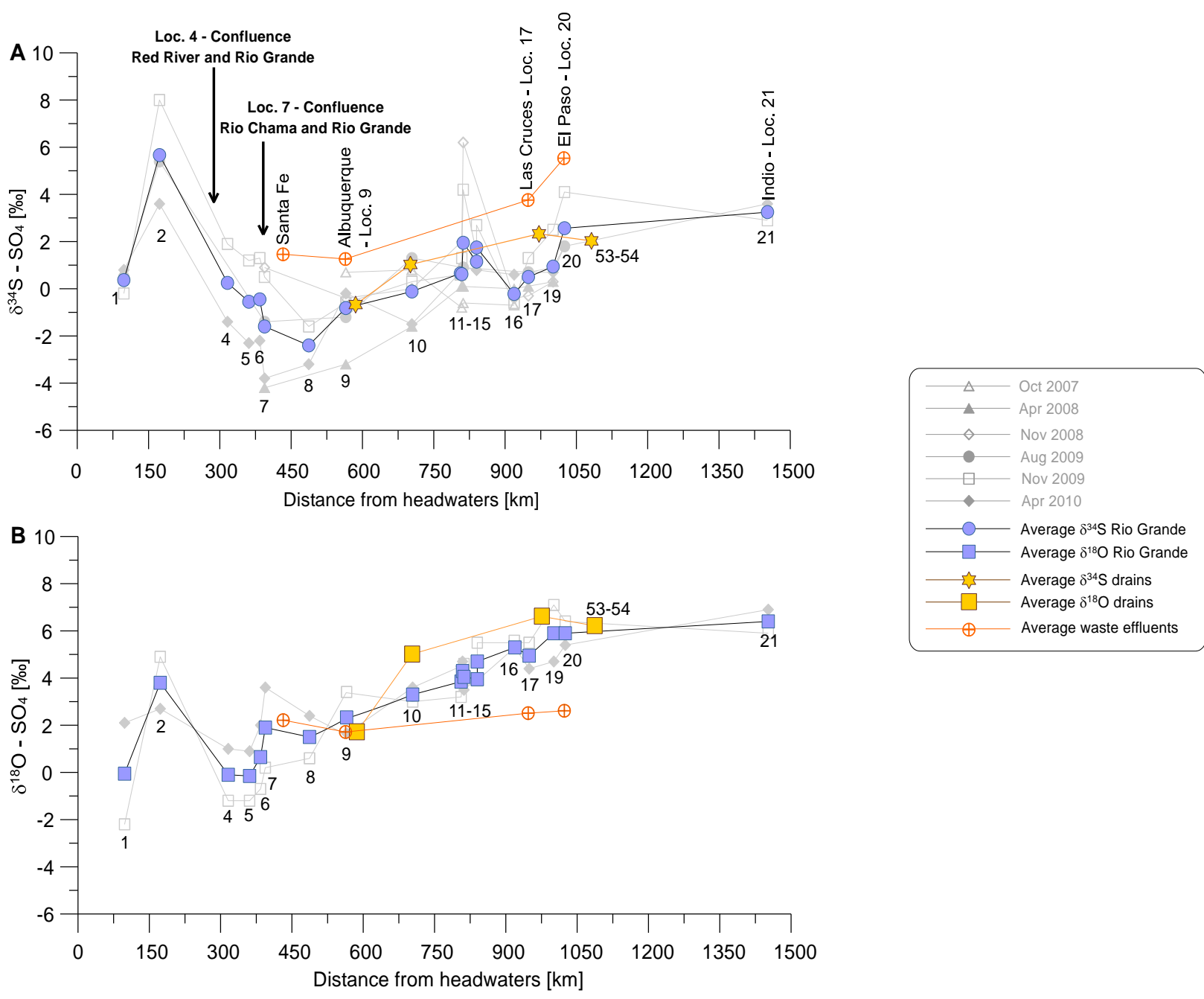
Figure 5. Variations of $\delta^{34} \mathrm{~S}$ versus $\delta^{18} \mathrm{O}$ in the Rio Grande, upstream tributaries, and groundwater. Numbers indicate sampling locations shown on Figure 1. For figure in color, the reader is referred to the web version of this article.

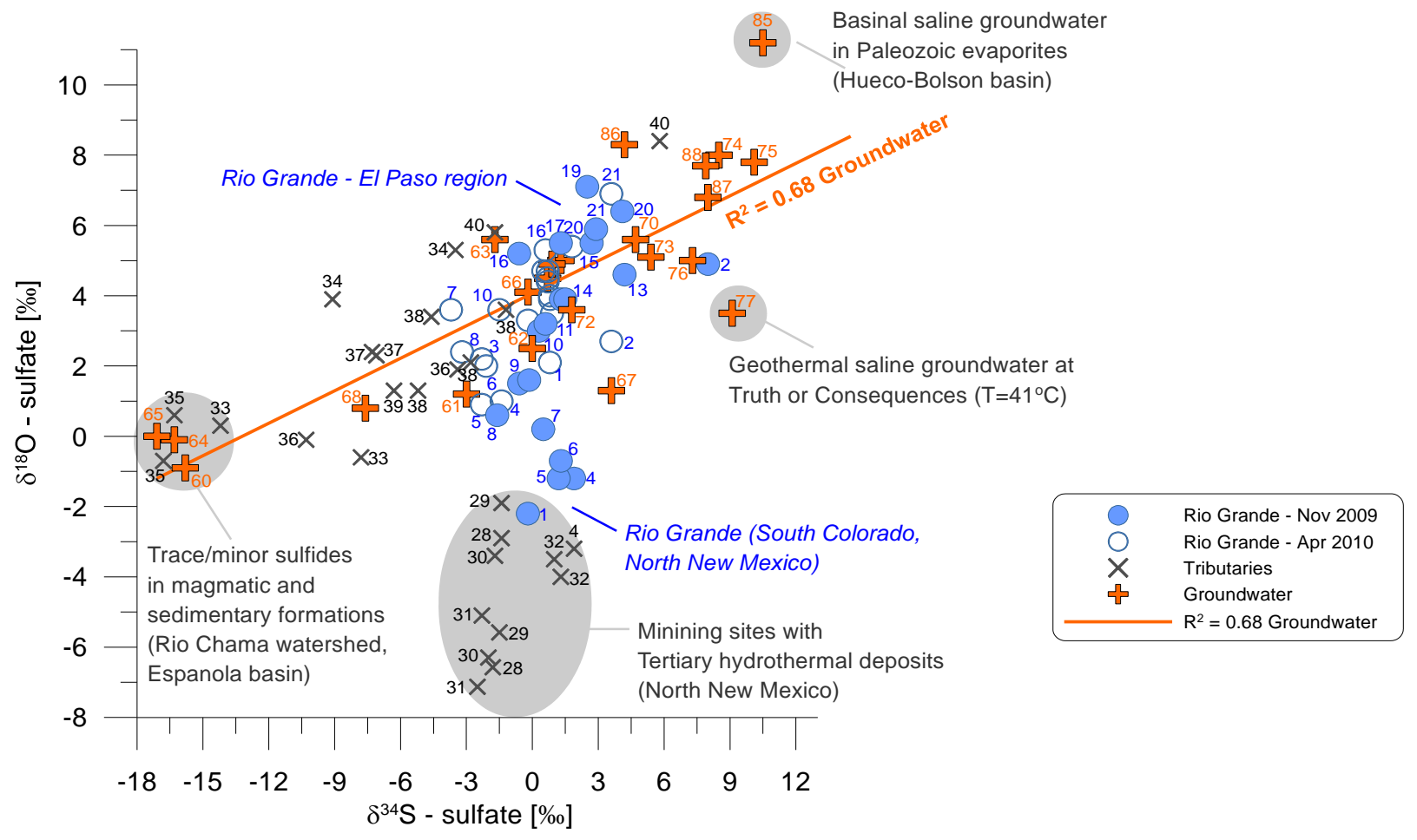


Figure 6. Variations of $\delta^{34} \mathrm{~S}$ (brown dots) and $\delta^{18} \mathrm{O}$ (black squares) along the Rio Chama, a major tributary to the Rio Grande in northern New Mexico. For figure in color, the reader is referred to the web version of this article.

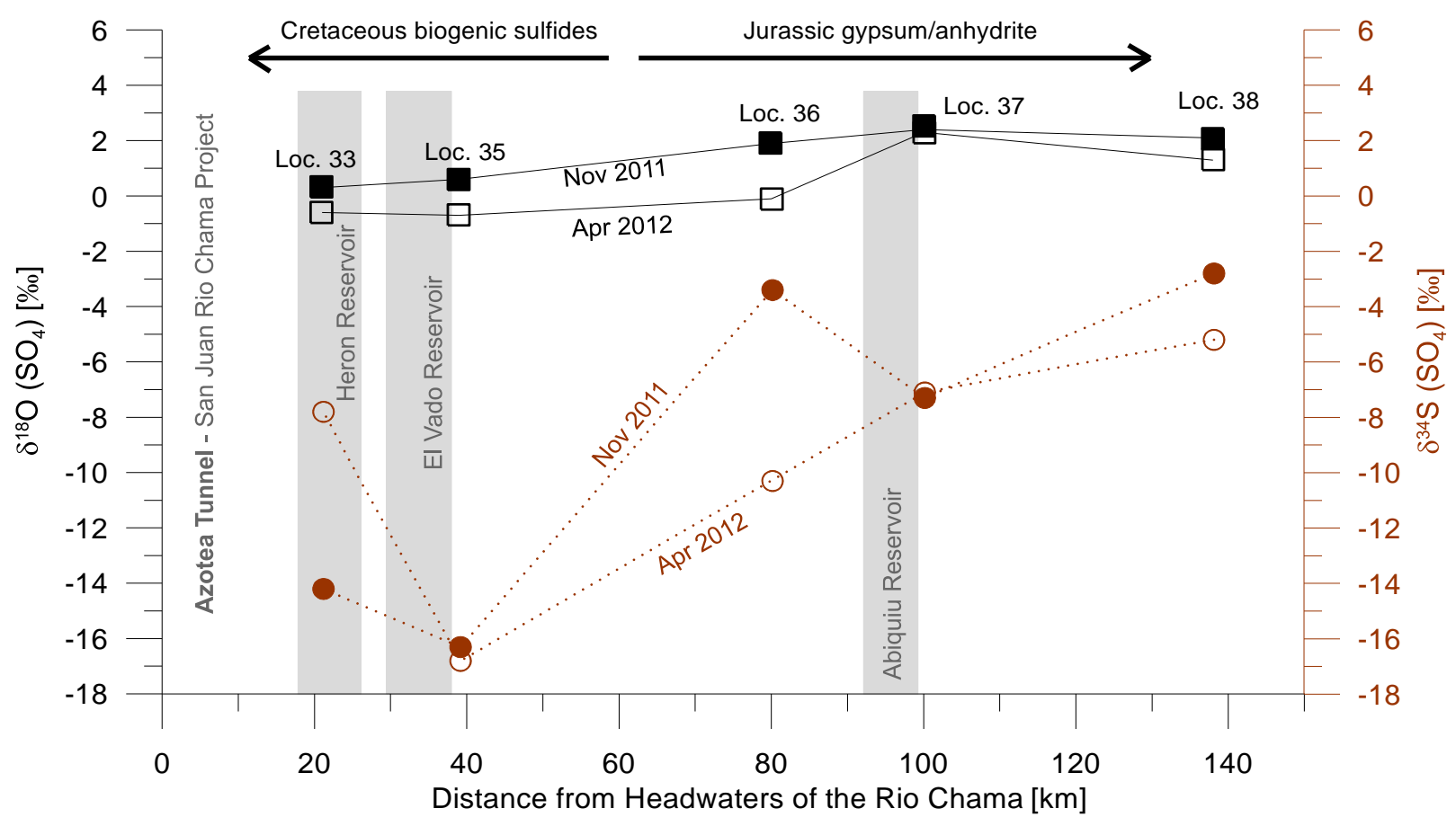


Figure 7. Variations of reciprocal $\mathrm{SO}_{4}$ concentrations and flux versus $\delta^{34} \mathrm{~S}$ in the Rio Grande during nonirrigation (November 2009) and irrigation (April 2010) seasons. Numbers indicate sampling locations shown on Figure 1. Because of high values of reciprocal $\mathrm{SO}_{4}$ concentrations plotting outside the presented concentrations range (>0.4), the samples no. 1 and 2 are not presented on graph A. For figure in color, the reader is referred to the web version of this article.
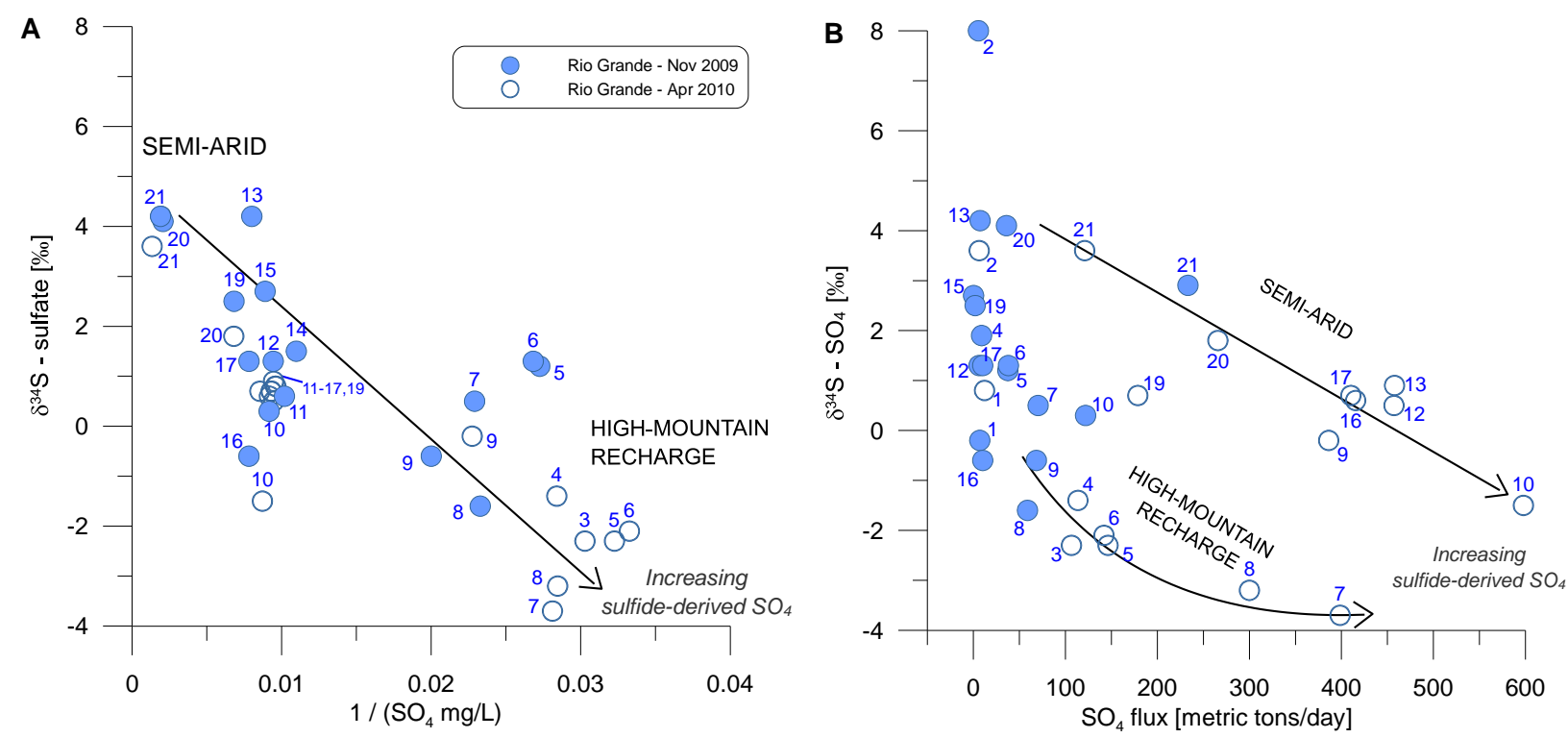
Figure 8. Contributions of sulfide-derived $\mathrm{SO}_{4}[\%]$ compared to sulfate (evaporite)-derived $\mathrm{SO}_{4}$ in the Rio Grande and major tributaries in upstream locations. Bars indicate uncertainty of the $\mathrm{S}$ isotope mass balance constraint (See Tables 2 and 3 for more details). Numbers indicate sampling locations shown on Figure 1. Note that the $\mathrm{SO}_{4}$ flux for the Rio Puerco was estimated using stream $\delta^{34} \mathrm{~S}$ for the period 19971998 reported by Plummer et al. (2004). For figure in color, the reader is referred to the web version of this article.

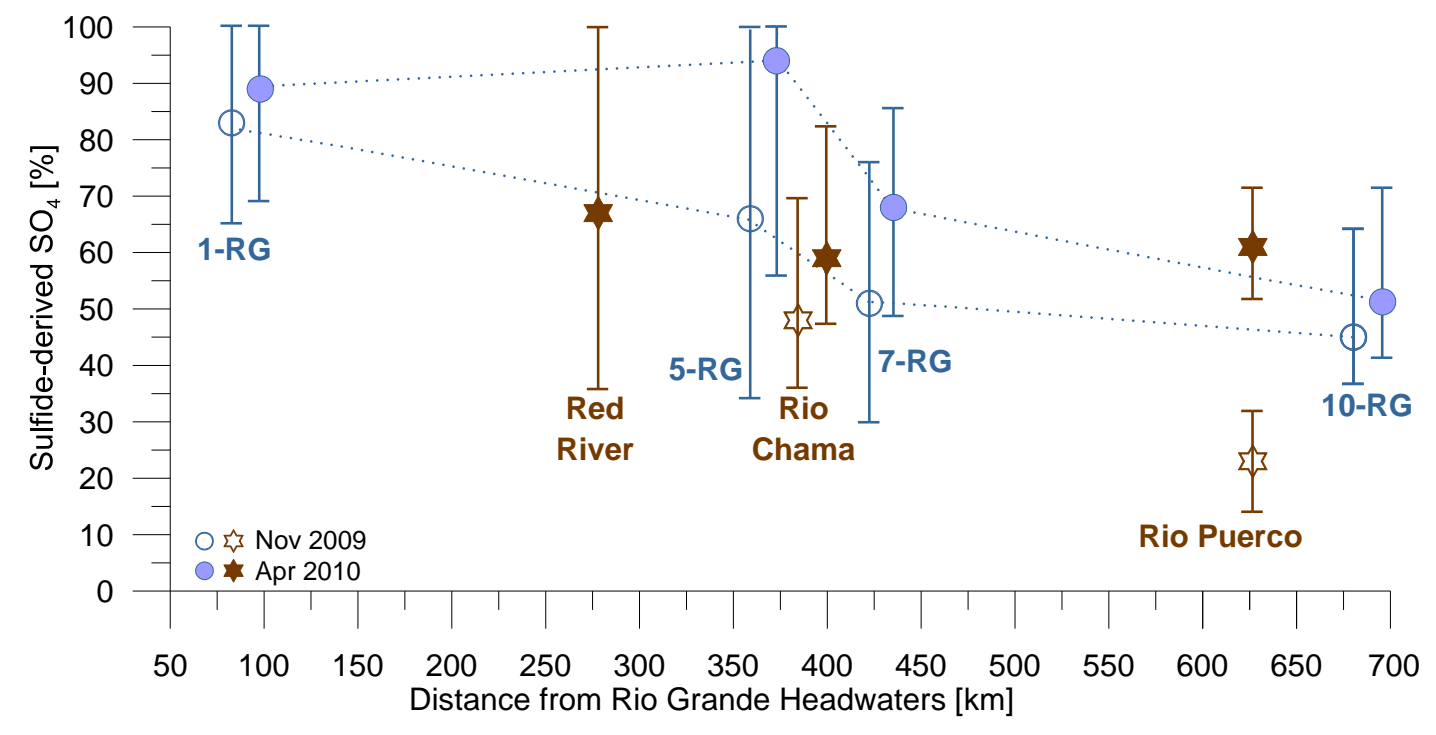


Table 1. The measured sulfide-derived $\mathrm{SO}_{4}$ fluxes in various hydrological catchments and river basins across the world. These fluxes were calculated using sulfur isotope mass balance (except for Wadham et al. 1998).

\begin{tabular}{|l|l|l|}
\hline Location & $\begin{array}{l}\text { Sulfide-derived SO } \\
{[\%]}\end{array}$ & Reference \\
\hline Glacier catchments (Svalbard, Norway) & $\sim 100$ & $\begin{array}{l}\text { Szynkiewicz et al. (2013) } \\
\text { Wadham et al. (1998) }\end{array}$ \\
\hline Kaoping River basin (South Taiwan) & $\sim 85 \pm 7$ & Das et al. (2012) \\
\hline MacKenzie River basin (Canada) & $\sim 85 \pm 5$ & Calmels et al. (2007) \\
\hline Canadian Cordillera (Canada) & $\sim 81 \pm 10$ & Spence and Telmer (2005) \\
\hline Beipanjijang River basin (Southwest China) & $\sim 60 \pm 4$ & Li et al. (2008) \\
\hline $\begin{array}{l}\text { Upper Rio Grande basin (South Colorado/North New } \\
\text { Mexico, USA) }\end{array}$ & $\sim 51-94 \pm 10-20$ & This study \\
\hline $\begin{array}{l}\text { Middle Rio Grande basin (North/Central New Mexico, } \\
\text { USA) }\end{array}$ & $\sim 23-61 \pm 10-20$ & This study \\
\hline Sacramento Mountains (Southeast New Mexico, USA) & $\sim<14 \pm 4-7$ & Szynkiewicz et al. (2012) \\
\hline
\end{tabular}

Table 2. Maximum and minimum values of $\delta^{34} \mathrm{~S}$ in the major $\mathrm{SO}_{4}$ endmembers in the Rio Grande watershed. Abbreviations: $\mathrm{n}$ - number of samples analyzed, Ave. - average, n.a. - not analyzed.

\begin{tabular}{|c|c|c|c|c|c|c|}
\hline \multirow{2}{*}{$\begin{array}{l}\text { End } \\
\text { member } \\
\text { No. }\end{array}$} & \multirow[t]{2}{*}{ Location } & \multirow[t]{2}{*}{ Bedrock Type } & \multicolumn{2}{|c|}{$\mathrm{SO}_{4}$ endmember } & \multirow[t]{2}{*}{ Reference } & \multirow{2}{*}{$\begin{array}{l}\text { Locations of } \\
\text { occurrence } \\
\text { (No. on Fig.1) }\end{array}$} \\
\hline & & & Sulfide [\%o] & Sulfate [\%o] & & \\
\hline 1 & $\begin{array}{l}\text { San Juan Mnts., } \\
\text { Rio Grande } \\
\text { Headwaters } \\
\text { (South Colorado) }\end{array}$ & $\begin{array}{l}\text { Tertiary } \\
\text { Hydrothermal }\end{array}$ & $\begin{array}{l}-6.9 \text { to }+2.5 \\
\text { (Ave. }-2.3 \\
n=17 \text { ) }\end{array}$ & $\begin{array}{l}+14.6 \text { to }+18.0 \\
\text { (Ave. }+16.5 ; \\
n=6)\end{array}$ & $\begin{array}{l}\text { Nordstrom } \\
\text { et. al. (2007) }\end{array}$ & $1,22-27$ \\
\hline 2 & $\begin{array}{l}\text { Red River Valley } \\
\text { (North New } \\
\text { Mexico) }\end{array}$ & $\begin{array}{l}\text { Tertiary } \\
\text { Hydrothermal }\end{array}$ & $\begin{array}{l}-8.9 \text { to }+2.7 \\
\text { (Ave. }-3.1 \\
n=13 \text { ) }\end{array}$ & $\begin{array}{l}+6.6 \text { to }+12.6 \\
\text { (Ave. }+9.7 \\
n=13)\end{array}$ & $\begin{array}{l}\text { Campbell } \\
\text { and Lueth } \\
\text { (2008) }\end{array}$ & $3-6,28-32$ \\
\hline 3 & $\begin{array}{l}\text { Central/South } \\
\text { New Mexico }\end{array}$ & $\begin{array}{l}\text { Permian } \\
\text { marine } \\
\text { evaporites }\end{array}$ & n.a. & $\begin{array}{l}+10.9 \text { to }+15.1, \\
\text { (Ave. }+12.8 \\
\mathrm{n}=23 \text { ) }\end{array}$ & $\begin{array}{l}\text { Szynkiewicz } \\
\text { et al. (2011) }\end{array}$ & $9-20$ \\
\hline 4 & $\begin{array}{l}\text { Northwest New } \\
\text { Mexico }\end{array}$ & $\begin{array}{l}\text { Jurassic } \\
\text { marine } \\
\text { evaporites }\end{array}$ & n.a. & $\begin{array}{l}+15.1 \text { to }+17.7 \text {, } \\
\text { (Ave. } \\
+16.1 ; \mathrm{n}=11 \text { ) }\end{array}$ & $\begin{array}{l}\text { Kirkland et } \\
\text { al. (1995) }\end{array}$ & $\begin{array}{l}7-9,33-38 \\
39-40\end{array}$ \\
\hline 5 & $\begin{array}{l}\text { Northwest/Central } \\
\text { New Mexico }\end{array}$ & $\begin{array}{l}\text { Cretaceous } \\
\text { sandstone, } \\
\text { shale, coal }\end{array}$ & $\begin{array}{l}-22.3 \text { to }-9.5, \\
\text { (Ave. }-18.0 \\
n=6)\end{array}$ & n.a. & $\begin{array}{l}\text { Szynkiewicz } \\
\text { et al. (2014) }\end{array}$ & $\begin{array}{l}7-9,33-38 \\
39-40\end{array}$ \\
\hline
\end{tabular}


Table 3. Using sulfur isotope $\left(\delta^{34} \mathrm{~S}\right)$ mass balance constraint, the estimation of sulfide-derived $\mathrm{SO}_{4}$ flux in the selected location along the Rio Grande compared to sulfate(evaporite)-derived $\mathrm{SO}_{4}$. See Table 2 for the end-member number and its maximum, minimum, and average $\delta^{34} \mathrm{~S}$ values used in the $\mathrm{S}$ isotope mass balance.

\begin{tabular}{|l|l|l|l|l|l|l|l|}
\hline Location & Condition & $\begin{array}{l}\text { Endmember } \\
\text { used (Tab. 2) }\end{array}$ & $\begin{array}{l}\boldsymbol{\delta}^{\mathbf{3 4}} \mathbf{S} \\
{[\mathbf{\% o}]}\end{array}$ & $\begin{array}{l}\text { Min } \\
{[\%]}\end{array}$ & $\begin{array}{l}\text { Max } \\
{[\%]}\end{array}$ & $\begin{array}{l}\text { Average } \\
{[\%]}\end{array}$ & $\begin{array}{l}\text { Uncertainty } \\
+/-[\%]\end{array}$ \\
\hline 1 Rio Grande & Baseflow (Nov 2009) & 1 & +0.8 & 65 & 100 & 83 & 18 \\
\hline 1 Rio Grande & Snowmelt (Apr 2010) & 1 & -0.2 & 69 & 100 & 89 & 16 \\
\hline 5 Rio Grande & Baseflow (Nov 2009) & 2 & +1.3 & 34 & 100 & 66 & 33 \\
\hline 5 Rio Grande & Snowmelt (Apr 2010) & 2 & -2.1 & 56 & 100 & 94 & 22 \\
\hline 7 Rio Grande & Baseflow (Nov 2009) & 2 & +0.5 & 30 & 76 & 51 & 23 \\
\hline 7 Rio Grande & Snowmelt (Apr 2010) & 2 & -3.7 & 47 & 83 & 68 & 18 \\
\hline 10 Rio Grande & Baseflow (Nov 2009) & $3,4,5$ & +0.3 & 37 & 64 & 45 & 14 \\
\hline 10 Rio Grande & Snowmelt (Apr 2010) & $3,4,5$ & -1.5 & 41 & 71 & 51 & 15 \\
\hline 32 Red River & Snowmelt (Apr 2010) & 2 & +1.0 & 36 & 100 & 67 & 32 \\
\hline 38 Rio Chama & Baseflow (Nov 2009) & 4,5 & -1.2 & 36 & 70 & 48 & 17 \\
\hline 38 Rio Chama & Snowmelt (Apr 2010) & 4,5 & -4.6 & 47 & 82 & 59 & 18 \\
\hline *40 Rio Puerco & Baseflow (Dec 1998) & $3,4,5$ & +5.9 & 14 & 32 & 23 & 9 \\
\hline *40 Rio Puerco & Snowmelt (May 1998) & $3,4,5$ & -8.3 & 52 & 71 & 61 & 10 \\
\hline
\end{tabular}

$*-\delta^{34} \mathrm{~S}$ of riverine sulfate after Plummer et al. (2004) 